\title{
ORGANIZIRANO PRIKUPLJANJE PUNOMOĆI ZA GLASOVANJE NA GLAVNOJ SKUPŠTINI KAO MODALITET UTJECANJA NA DONOŠENJE ODLUKA U DRUŠTVU - OTVORENA PITANJA ${ }^{1}$
}

Dr. sc. Antonija Zubović, docentica

Pravni fakultet Sveučilišta u Rijeci
UDK: 347.722

Ur.: 17. siječnja 2017.

Pr.: 10. veljače 2017.

Izvorni znanstveni rad

\section{Sažetak}

U radu se obrađuje organizirano prikupljanje punomoći za glasovanje na glavnoj skupštini, ukazujući na otvorena pitanja u njegovoj primjeni. Budući da Direktiva o pravima dioničara u uvrštenim društvima ne uređuje izričito ovaj institut, države članice EU-a zauzele su različita stajališta u pogledu njegova uređenja. S jedne strane su države članice koje nisu izričito uredile organizirano prikupljanje punomoći za glasovanje na glavnoj skupštini, dok su s druge strane države članice koje posebnim odredbama uređuju ovaj institut. Međutim, $i$ unutar te skupine država članica uočavaju se različiti pristupi u uređenju pojedinih pitanja. Valja istaknuti da se u državama članicama EU-a u kojima nije izričito uređeno organizirano prikupljanje punomoći za glasovanje na glavnoj skupštini, sve više postavlja pitanje potrebe njegova regulatornog uređenja. Stoga se zaključno daju prijedlozi rješenja za hrvatsko pravo.

Ključne riječi: organizirano prikupljanje punomoći za glasovanje na glavnoj skupštini, punomoći, opunomoćenik, glavna skupština, pravo glasa, Direktiva o pravima dioničara.

\section{1. $U V O D$}

Prikupljanje punomoći za glasovanje na glavnoj skupštini jedan je od modaliteta utjecanja na donošenje ključnih odluka u društvu koje su u nadležnosti glavne skupštine. Valja istaknuti da ako određena osoba pokreće postupak organiziranoga prikupljanja punomoći za glasovanje na glavnoj skupštini, ona ima interes za donošenje odluka određenoga sadržaja, odnosno njene su namjere utjecati na odluke koje se trebaju donijeti na glavnoj skupštini za koju se prikupljaju punomoći. Dakle,

1 Ovaj rad su sufinancirali Hrvatska zaklada za znanost projektom br. 9366 "Pravni aspekti korporativnih akvizicija i restrukturiranje društava utemeljenih na znanju" te Sveučilište u Rijeci projektom br. 13.08.1.2.01 "Zaštita korisnika na hrvatskom i europskom tržištu financijskih usluga". 
njezin je cilj stjecanje ili učvršćivanje kontrole nad donošenjem odluka na glavnoj skupštini društva. ${ }^{2}$

Karakteristika je ovog načina stjecanja kontrole što ne dolazi do promjene u dioničarskoj strukturi, budući da opunomoćenik, za razliku od stjecanja dionica u postupku preuzimanja, ne kupuje dionice društva, već samo stječe ovlast za glasovanje na glavnoj skupštini. Dakle, taj postupak provodi se po puno nižim troškovima od primjerice postupka preuzimanja. To je jedan od motiva zbog kojega se određeni dioničari odlučuju upravo za ovaj postupak. Međutim, treba istaknuti da oni u ovom postupku stječu pravo glasovati po dionicama za koje su dobili punomoći te glasuju u ime dioničara, stoga ako je dioničar dao uputu kako glasovati po dionicama, oni su dužni postupati u skladu s njom. Stoga će njima biti u interesu dobiti punomoć bez uputa za glasovanje na glavnoj skupštini ili će se pak, s druge strane, izložiti sankcijama ukoliko glasuju u skladu sa svojom voljom ne poštujući volju dioničara. Dakle, jedno od otvorenih pitanja je pitanje kako pravni poredci uređuju slučajeve kada opunomoćenik glasuje protivno uputi koju je dobio od dioničara.

Ujedno, ako je dioničaru isključeno pravo glasa na glavnoj skupštini, postavlja se pitanje može li on glasovati kao opunomoćenik na glavnoj skupštini na kojoj mu je isključeno pravo glasa. Ako bi dobio punomoć bez upute kako glasovati o pojedinoj točki dnevnog reda, time bi "zaobišao" cilj odredbe kojom mu je isključeno njegovo pravo glasa. Stoga se zauzima stajalište da osoba kojoj je isključeno pravo glasa na glavnoj skupštini ne može glasovati niti kao opunomoćenik drugog dioničara. ${ }^{3}$ Takvo je stajalište izričito zauzeto u hrvatskom i njemačkom pravu.

Dalje se otvara pitanje postojanja sukoba interesa između opunomoćenika i opunomoćitelja. S tim se je pitanjem suočio i europski zakonodavac kod donošenja Direktive o pravima dioničara u uvrštenim društvima ${ }^{4}$ (dalje u tekstu: Direktiva o pravima dioničara). Ponajprije se nastojalo obuhvatiti slučajeve postojanja sukoba

2 U doktrini se kontrola najčešće definira kao držanje određenoga postotka glasačkih prava u društvu čime se utječe na donošenje ključnih odluka, kojima se može posredno ili neposredno utjecati na poslove društva. Parać, Zoran, Dileme oko preuzimanja javnih dioničkih društava, Pravo u gospodarstvu, god. 42., svezak 4., 2003., str. 45., Petrović, Siniša, Pripajanje dioničkih društava i druge koncentracije u pravu društava (doktorska disertacija), Pravni fakultet u Zagrebu, 1998., str. 103.

3 Hüffer, Üve, Aktiengesetz Kommentar, 9. Auflage, 2010. § 136 Rn. 6; Lieberam-Schmidt, Sabine, Die Stimmrechtsvertretung im Aktien- und GmbH-Recht, Dissertation, 2010., str. 32.33.

4 Directive 2007/36/EC of the European Parliament and of the Council of 11 July 2007 on the exercise of certain rights of shareholders in listed companies, OJ L 184, 14. 7. 2007., str. 17.24. U svojoj odluci od 21. travnja 2004. godine, OJ C 104 E of April 30, 2004, str. 426. Europski parlament je izrazio svoju podršku istaknutim namjerama Komisije. Vezano za ostvarivanje prava glasa dioničara istaknula su se četiri temeljna problema: a) problem pristupa informacijama koje su relevantne za održavanje glavne skupštine, b) problematika obveze blokiranja (pohrane dionica) prije održavanja glavne skupštine, kao uvjet za ostvarivanje prava glasa (engl. share blocking), c) glasovanje preko opunomoćenika i d) primjena modernih tehnologija u glasovanju. O motivima donošenja Direktive o pravima dioničara u uvrštenim društvima vidjeti više kod Čulinović-Herc, Edita, Hasić, Tea, Sudjelovanje dioničara u radu glavne skupštine dioničkog društva prema noveli Zakona o trgovačkim društvima, Zbornik Pravnog fakulteta u Rijeci, vol. 32., br. 1., 2011., str. 36.-37. 
interesa te zauzeti stajalište na koji način države članice mogu postupiti u tim slučajevima. Valja istaknuti da odredbe Direktive o pravima dioničara predstavljaju regulatorni minimum, stoga su države članice ovlaštene propisati i druge slučajeve postojanja sukoba interesa kao i strožije zahtjeve od onih propisanih Direktivom. Dakle moguće je postojanje različitih rješenja u državama članicama EU-a u pogledu uređenja ovog instituta.

Praksa pokazuje da se najčešće kao osobe koje provode postupak organiziranog prikupljanja punomoći pojavljuju udruge dioničara ili financijske institucije koje već drže određeni postotak dionica, na koji način jačaju svoju glasačku snagu na glavnoj skupštini. ${ }^{5}$ Valja istaknuti da određeni pravni poredci dopuštaju financijskim institucijama glasovati po dionicama koje imaju u svom skrbništvu čak i kada nisu dobili upute za glasovanje na glavnoj skupštini. To otvara daljnja pitanja, primjerice postojanje sukoba interesa ako financijska institucija istovremeno ima sklopljen neki od poslovnih aranžmana s društvom, primjerice ako ga kreditira.

Nužno je naglasiti da opunomoćenik na glavnoj skupštini ne ostvaruje samo pravo glasa po dionicama za koje su mu dane punomoći, već ostvaruje i ostala upravljačka prava dioničara. Tako on na glavnoj skupštini ostvaruje i pravo na raspravljanje, čime može utjecati na donošenje odluka glavne skupštine i glasovanje ostalih dioničara. Dakle, možemo reći da punomoć predstavlja određenu "ulaznicu“ na glavnu skupštinu onim osobama koje ne drže dionice društva u kom djeluju kao opunomoćenici. Ako bi te osobe pokrenule postupak organiziranoga prikupljanja punomoći za glasovanje na glavnoj skupštini i u tomu uspjele, one bi mogle utjecati na donošenje odluka na glavnoj skupštini u društvu, a da prije uopće nisu bili dioničari tog društva ili su, primjerice, bili u zanemarivom postotku.

Zadatak je ovoga rada, s jedne strane dati pregled uređenja organiziranoga prikupljanja punomoći za glasovanje na glavnoj skupštini u hrvatskom i poredbenim pravnim sustavima, ukazujući na otvorena pitanja koja se pojavljuju kod primjene ovog instituta $\mathrm{u}$ ispitivanim pravnim poredcima. Valja istaknuti da se u državama članicama EU-a u kojima nije izričito uređen ovaj institut sve više postavlja pitanje potrebe njegovog uređenja. Stoga se zaključno daju prijedlozi rješenja za hrvatsko pravo.

\section{ORGANIZIRANO PRIKUPLJANJE PUNOMOĆI ZA GLASOVANJE NA GLAVNOJ SKUPŠTINI}

\subsection{Europski regulatorni okvir}

Radi jačanja prava dioničara, u europskom pravu donesena je Direktiva o pravima dioničara koja kroz nekoliko odredaba uređuje glasovanje dioničara putem

5 Mayson, Stephen, French, Derek, Ryan, Christopher, Company Law, Oxford University Press, 2013, str. 389., Hannigan, Brenda, Company law, Third edition, Oxford University Press, 2012., str. 326., Cziraki, Peter, Renneboog, Luc, Szilagyi, Peter, G., Shareholder Activism through Proxy Proposals: The European Perspective, http://ssrn.com/abstract=1413125, str. 15. (posjećeno 20.12.2016.). 
opunomoćenika (engl. proxy voting). Već se u 10. točki preambule Direktive naglašava važnost glasovanja putem opunomoćenika i utjecaj takva oblika glasovanja na korporacijsko upravljanje te se apostrofira potreba uklanjanja postojećih ograničenja koja ovaj vid glasovanja čine skupim i složenim. Ujedno se naglašava da dobro korporacijsko upravljanje zahtijeva odgovarajuću zaštitu protiv moguće zloporabe takvog načina glasovanja. Kako bi se postigao taj cilj, nameće se obveza državama članicama usvojiti odgovarajuće mjere kojima se osigurava djelovanje opunomoćenika $\mathrm{u}$ interesu dioničara.

Sukladno odredbama Direktive, dioničari imaju pravo imenovati osobu koja će biti prisutna na glavnoj skupštini i koja će glasovati u njihovo ime. Međutim, Direktiva ne utječe na pravila ili sankcije koje je propisala država članica vezano za osobe koje ostvaruju pravo glasa na temelju fraudoloznog korištenja pribavljenih punomoći. Ujedno, Direktiva ne nameće nikakve obveze društvima u pogledu provjere ostvaruju li opunomoćenici pravo glasa u skladu s uputama dioničara.

U čl. 5. Direktive izričito se propisuje da "ne dovodeći u pitanje odredbu čl. 9. st. 4. i čl. 11. st. 4. Direktive o ponudama za preuzimanje, ${ }^{6}$ države članice trebaju osigurati da društva objave poziv za glavnu skupštinu na neki od načina propisan Direktivom, u roku koji ne smije biti kraći od 21 dana prije njenog održavanja“. Dalje se propisuje minimalni sadržaj poziva, gdje je, između ostaloga, propisano da on mora sadržavati jasan i precizan opis postupaka koji dioničari moraju ispuniti kako bi mogli sudjelovati na glavnoj skupštini i ostvarivati svoje pravo glasa, što uključuje i informacije o postupku glasovanja putem opunomoćenika.

Glasovanje putem opunomoćenika eksplicitno se propisuje odredbama čl. 10. Direktive. U čl. 10. st. 1. Direktive propisuje se pravo svakog dioničara imenovati pravnu ili fizičku osobu kao opunomoćenika, koja će sudjelovati i glasovati na glavnoj skupštini u njegovo ime. Stoga, opunomoćenik može biti osoba koja nema niti jednu dionicu društva. ${ }^{7}$ Opunomoćenik ima ista prava na raspravljanje i postavljanje pitanja na glavnoj skupštini na koja je ovlašten dioničar koji mu je dao punomoć. Državama članicama propisana je obveza ukinuti svaku zakonsku odredbu koja ograničava ili dopušta društvima ograničiti sposobnost osobe koja može biti imenovana kao opunomoćenik. Međutim, ova se obveza ne odnosi na zahtjev kojim se traži da opunomoćenik ima poslovnu sposobnost.

Odredbom Direktive dana je mogućnost državama članicama ograničiti imenovanje opunomoćenika na pojedinu glavnu skupštinu ili na glavne skupštine koje se održavaju u određenom vremenskom razdoblju. Ujedno, države članice mogu ograničiti broj osoba kojima dioničari mogu dati punomoć na pojedinoj glavnoj skupštini. Međutim, ukoliko dioničar ima dionice društva zabilježene na više računa, to ograničenje ne sprječava dioničara imenovati različite opunomoćenike ovisno o dionicama koje drži na svakom pojedinom računu u odnosu na pojedinu glavnu skupštinu. Dalje je propisano da ova odredba ne utječe na pravila propisana

6 Directive 2004/25/EC of the European Parliament and of the Council of 21 April 2004 on takeover bids, OJ L 142, 30. 4. 2004., str. 12-23.

7 Schneider, Anzinger, Institutionelle Stimmrechtsberatung und Stimmrechtsvertretung - "A quiet guru's enormous clout", Neue Zeitschrift für Gesellschaft, br. 88., 2007., str. 92. 
mjerodavnim pravom koja zabranjuju različito glasovanje po dionicama koje drži jedan dioničar. ${ }^{8}$ To znači da, ako dioničar ima više različitih opunomoćenika za dionice koje drži na različitim računima, oni ne mogu različito glasovati, ako je to zabranjeno mjerodavnim nacionalnim pravom.

Odredbom čl. 10. st. 3. Direktive navedeni su zahtjevi koje može odrediti država članica za slučaj postojanja sukoba interesa između opunomoćenika i dioničara u čije ime glasuje opunomoćenik. Tako su dane sljedeće mogućnosti državama članicama: a) propisati obvezu opunomoćenicima objaviti određene činjenice koje mogu biti bitne za dioničare u snošenju rizika vezanog za činjenicu da opunomoćenik zastupa interes koji nije interes dioničara; b) ograničiti ili isključiti ostvarivanje prava glasa dioničara putem opunomoćenika bez posebnih uputa o glasovanju za pojedinu odluku za koju opunomoćenik treba glasovati u ime dioničara; c) ograničiti ili isključiti pravo prijenosa punomoći na drugu osobu, ali to ne ograničava opunomoćenika koji je pravna osoba od ostvarivanja danih ovlasti putem članova njegovih upravnih ili upravljačkih tijela ili putem zaposlenika.

Sukladno odredbama Direktive, do sukoba interesa može doći kada je opunomoćenik: (i) dioničar koji kontrolira društvo (engl. controlling shareholder) ili je drugi subjekt kojega kontrolira takav dioničar; (ii) član upravnog, upravljačkog ili nadzornog tijela društva ili dioničara koji kontrolira društvo ili subjekta kojega kontrolira takav dioničar; (iii) zaposlenik ili revizor društva ili dioničara koji kontrolira društvo ili subjekta kojega kontrolira takav dioničar; (iv) u obiteljskoj vezi s fizičkom osobom iz prethodnih točaka (od i-iii). ${ }^{9}$ Nužno je istaknuti da Direktiva ne definira dioničara koji kontrolira društvo (engl. controlling shareholder) niti obiteljsku vezu (engl. family relationship). Valja naglasiti i da Direktiva propisuje samo minimum pravila koja su države članice dužne usvojiti, stoga bi one mogle ovom odredbom obuhvatiti i druge slučajeve postojanja sukoba interesa. ${ }^{10}$

Na temelju izričite odredbe čl. 10. st. 4. Direktive, opunomoćenik je dužan glasovati u skladu s uputama dioničara. ${ }^{11}$ No, Direktiva ne propisuje sankcije ako opunomoćenik ne glasuje u skladu s dobivenim uputama.

Odredbama Direktive ne ograničava se broj punomoći koje može imati pojedini opunomoćenik. Tako on može glasovati na glavnoj skupštini kao opunomoćenik više dioničara. Kada opunomoćenik djeluje u ime više dioničara, mjerodavnim pravom mora mu se omogućiti zasebno glasovanje za svakoga pojedinog dioničara koji mu je dao punomoć.

8 Čl. 10. st. 2. Direktive o pravima dioničara.

9 Čl. 10. st. 3. Direktive o pravima dioničara.

10 Masouros, E., Pavlos, Is the EU Taking Shareholder Rights Seriously?: An Essay on the Impotence of Shareholdership in Corporate Europe, European Company Law, vol. 7., br. 5., 2010., str. 199. Ratschow, Eckart, Die Aktionärsrechte-Richtlinie - neue Regeln für börsennotierte Gesellschaften, Deutsches Steuerrecht, br. 32., 2007., str. 1407. Noack, Ulrich, Die Aktionärsrechte-Richtlinie, u: Festschrift für Harm Peter Westermann zum 70. Geburtstag, Verlag Dr. Otto Schmidt, Köln, 2008., str. 1212. Ochmann, Florian, Die ActionärsrechteRichtlinie, Auswirkungen auf das deutsche und europäische Recht, De Gruyter Recht, Berlin, 2009., str. 153-154.

11 Ujedno, države članice mogu zahtijevati od punomoćnika da čuva ispravu o uputama kako glasovati određeni vremensko razdoblje te da na zahtjev potvrdi da su poštovane dane upute. 
Odredbama čl. 11. Direktive uređuju se formalnosti koje moraju biti ispunjene za imenovanje opunomoćenika. Države članice moraju dopustiti dioničarima imenovanje opunomoćenika elektroničkim putem, te društva obvezati da prihvate obavijest o imenovanju opunomoćenika elektroničkim putem. Izričito je propisano da imenovanje opunomoćenika i obavijest društvu o imenovanju opunomoćenika moraju biti u pisanom obliku. Nacionalni zakonodavci nisu ovlašteni propisivati dodatne uvjete za valjanost imenovanja, osim onih koji su potrebni da bi se utvrdio identitet opunomoćenika i dioničara, te da bi se omogućila provjera sadržaja upute za glasovanje i to samo u onoj mjeri u kojoj su ti uvjeti razmjerni postizanju ovih ciljeva (čl. 11. st. 2. Direktive o pravima dioničara). ${ }^{12}$

Odredbom čl. 8. Direktive o pravima dioničara propisana je mogućnost sudjelovanja i glasovanja na glavnoj skupštini putem elektroničkih medija, stoga će i opunomoćenik moći ostvariti pravo glasa na navedeni način (engl. Electronic Proxy Voting - EPV).$^{13}$ Ističe se da Direktiva o pravima dioničara u tomu nadopunjuje Direktivu o transparentnosti. ${ }^{14}$ Ujedno se ovom odredbom olakšava ostvarivanje prava glasa po punomoćima koje su prikupljene u organiziranom postupku prikupljanja punomoći.

U prosincu 2012. godine Europska komisija je usvojila Akcijski plan o europskom pravu društava i korporacijskom upravljanju (Action Plan on European Company Law and Corporate Governance $)^{15} \mathrm{u}$ kojem je istaknuta nužnost revizije Direktive o pravima dioničara, radi povećanja sudjelovanja dioničara u donošenju odluka u društvu. U travnju 2014. godine Europska komisija podnijela je prijedlog izmjena Direktive o pravima dioničara, koji je ponajprije usmjeren na uklanjanje nedostataka vezanih za upravu/upravni odbor društva, institucionalne ulagatelje i asset managere kao dioničare društva, posrednike i osobe koje pružaju usluge dioničarima o načinu kako glasovati na glavnoj skupštini (engl. proxy advisors). ${ }^{16}$

12 Odredbe o uvjetima za imenovanje opunomoćenika primjenjuju se mutatis mutandis na opoziv punomoći (čl. 11. st. 3. Direktive o pravima dioničara).

13 Zetzsche, Dirk, Virtual Shareholder Meetings and the European Shareholder Rights Directive - Challenges and Opportunities, dostupno na: http://ssrn.com/abstract=998429, str. 10., 33., 59. (posjećeno 20.12.2016.), Zetzsche, Dirk, Shareholder Passivity, Cross-Border Voting and the Shareholder Rights Directive, dostupno na: http://ssrn.com/abstract=1120915, str. 45. (posjećeno 20.12.2016.)

14 Directive 2004/109/EC of the European Parliament and of the Council of 15 December 2005 on the harmonisation of transparency requirements in relation to information about issuers whose securities are admitted to trading on a regulated market and amending Directive 2001/34/EC, OJ L 390, 31.12.2004., str. 38-57.

15 Communication from the Commision to the European Parliament, the Council, the European Economic and Social Committee and the Committee of the Regions Action Plan: European company law and corporate governance - a modern legal framework for more engaged shareholders and sustainable companies, dostupno na: http://eur-lex.europa.eu/legal-content/ EN/TXT/?qid=1453891145338\&uri=CELEX:52012DC0740 (posjećeno 16.11.2016.).

16 Prije podnošenja prijedloga provedena su tri postupka javnih konzultacija. Godine 2010. objavljen je Green Paper on corporate governance in financial institutions, 2011. godine objavljen je Green Paper on the EU corporate governance framework te 2013. godine Green Paper on the long-term financing of the EU economy. Tekst prijedloga Direktive o pravima dioničara u uvrštenim društvima dostupan je na: http://eur-lex.europa.eu/legal-content/EN/ 
Jedan od potencijalnih problema na koji ukazuje praksa jeste odnos proxy advisora,${ }^{17} \mathrm{~s}$ jedne strane i osoba koje prikupljaju punomoći za glasovanje na glavnoj skupštini, dakle opunomoćenika, s druge. Dok prvi daju savjet kako glasovati po dionicama, drugi ostvaruju pravo glasa na glavnoj skupštini. Predlaže se objavljivanje postojanja sukoba interesa kada se ista osoba pojavljuje u ulozi savjetnika i opunomoćenika te objavljivanje mjera koje je proxy advisor poduzeo radi preveniranja sukoba interesa. ${ }^{18}$ Ujedno, ako bi se savjetnicima propisala obveza objavljivanja danih savjeta prije održavanja glavne skupštine to bi za njih predstavljalo dodatni problem. U takvoj bi situaciji izdavatelji mogli "nadmudriti“ savjetnike.

Dakle, sukladno odredbama Direktive o pravima dioničara, dopušteno je provođenje organiziranog prikupljanja punomoći za glasovanje na glavnoj skupštini. Iako je osnovno polazište Direktive, olakšanje izdavanja punomoći za glasovanje na glavnoj skupštini, njenim se odredbama nastoje prevenirati određene zloporabe toga instituta davanjem određenih prava državama članicama, primjerice ograničiti davanje punomoći na jednu glavnu skupštinu ili ograničiti broj opunomoćenika kojima se može dati punomoć. Ta bi se ograničenja učinkovito mogla koristiti kod organiziranog prikupljanja punomoći za glasovanje na glavnoj skupštini. Valja naglasiti da se polje primjene Direktive odnosi samo na društva koja su uvrstila svoje dionice na organizirano tržište kapitala. To znači da su društva koja nisu uvrstila svoje dionice na organizirano tržište kapitala izvan polja primjene Direktive i da bi za njih mogla vrijediti drukčija pravila.

\subsection{Rješenja usvojena u državama članicama EU-a}

Države članice EU-a uskladile su svoja zakonodavstva s odredbama Direktive o pravima dioničara. Međutim, budući da Direktiva izričito ne uređuje institut organiziranog prikupljanja punomoći, države članice su zauzele različita stajališta $\mathrm{u}$ pogledu njegova uređenja. S jedne je strane skupina država koje taj institut nisu uredile posebnim odredbama, već se na njega primjenjuju opće odredbe prava društava o imenovanju i glasovanju opunomoćenika, dok su s druge države članice koje su usvojile posebne odredbe kojima su uredile organizirano prikupljanje punomoći za glasovanje na glavnoj skupštini. Međutim, i unutar te grupe država članica EU-a postoje značajne razlike u njegovom uređenju.

Kao primjeri država članica EU-a koje nisu izričito uredile institut organiziranog prikupljanja punomoći za glasovanje na glavnoj skupštini, u radu se obrađuju odredbe njemačkog i hrvatskog zakonodavstva, dok se kao primjeri država članica koje su izričito uredile ovaj institut iznose rješenja u slovenskom, francuskom i talijanskom pravu.

TXT/?qid=1398680488759\&uri=COM:2014:213:FIN (posjećeno 16.11.2016.).

17 Sukladno definiciji danoj u Prijedlogu Direktive o pravima dioničara u uvrštenim društvima "proxy advisor" je pravna osoba koja, na profesionalnoj osnovi, daje prijedloge dioničarima o ostvarivanju njihovih glasačkih prava.

18 Summary of the informal discussion concerning the initiative on shareholders engagement, Brussels, 17 April 2013, str. 5., dostupno na: http://ec.europa.eu/internal_market/company/ docs/shareholders/120417_summary-initiative-shareholders-engagement_en.pdf (posjećeno 10.11.2016.). 


\subsubsection{Države članice koje nisu usvojile posebne odredbe o organiziranom prikupljanju punomoći za glasovanje na glavnoj skupštini}

Niti hrvatsko niti njemačko zakonodavstvo ne sadrže posebne odredbe kojima se izričito uređuje organizirano prikupljanje punomoći za glasovanje na glavnoj skupštini. Dakle, taj postupak nije podvrgnut posebnom režimu, a na glasovanje opunomoćenika koji bi prikupio punomoći u ovakvom postupku, kao i na sam postupak prikupljanja punomoći, primjenjivale bi se odredbe Zakona o trgovačkim društvima $^{19}$ (dalje u tekstu: ZTD) o glasovanju putem punomoćnika u hrvatskom pravu, odnosno u njemačkom pravu odredbe Zakona o dionicama ${ }^{20}$ (dalje u tekstu: AktG). ZTD u čl. 291. st. 6. kao i AktG u § 134. st. 3. daje pravo dioničaru ostvarivati svoje pravo glasa na glavnoj skupštini osobno ili putem opunomoćenika.

I u njemačkom i hrvatskom pravu propisane su posebne obveze vezane za sazivanje glavne skupštine, društvima koja su uvrstila svoje dionice na organizirano tržište kapitala. Ona su dužna već u pozivu za glavnu skupštinu navesti postupak glasovanja putem opunomoćenika s upućivanjem na formulare koje treba koristiti za davanje punomoći za glasovanje i na način kako se dokaz o imenovanju opunomoćenika može elektroničkim putem dostaviti društvu i postupak glasovanja pisanim putem ili putem elektroničke komunikacije, ako se statutom za to predviđa odgovarajući oblik korištenja pravom glasa (čl. 277. st. 4. t. 2. ZTD-a, § 121. st. 3. AktG-a). Ujedno im je odredbom čl. 280.a. ZTD-a i § 124.a AktG-a propisano da su dužna odmah nakon sazivanja glavne skupštine poduzeti sve da na njihovim internetskim stranicama budu dostupni obrasci koji se moraju upotrijebiti u glasovanju putem opunomoćenika, ako ih se neposredno ne dostavlja dioničarima. ${ }^{21}$ Riječ je o osiguravanju da su dioničarima dostupne informacije potrebne za ostvarivanje njihovih članskih prava. Propust da se to učini nema za posljedicu da su odluke donesene na toj skupštini pobojne (čl. 360. st. 3. t. 2. ZTD-a, § 243. st. 3. t. 2. AktG-a). ${ }^{22}$

Sukladno hrvatskom i njemačkom pravu, dioničar može dati punomoć jednoj ili više osobama. Ukoliko dioničar opunomoći više od jedne osobe, društvo može odbiti prihvatiti jednu ili više tako danih punomoći. Danom mogućnošću izbjegavaju se stanja neizvjesnosti do kojih može doći budući da više opunomoćenika moraju zajednički izjaviti volju u ime opunomoćitelja, što može imati za posljedicu zastoje u radu glavne skupštine kao i netočno utvrđivanje rezultata glasovanja. ${ }^{23}$ Ujedno se

19 Zakon o trgovačkim društvima, Narodne novine, br. 111/93, 34/99, 121/99, 52/00, 118/03, 107/07, 146/08, 137/09, 125/11, 152/11, 111/12, 68/13, 110/15.

20 Aktiengesetz vom 6. September 1965 (BGBl. I S. 1089), posljednji put izmijenjen čl. 5. Zakona od 10. 5. 2016. (BGB1. I S. 1142).

21 Ako formulari iz tehničkih razloga ne mogu biti dostupni na internetskoj stranici društva, na njoj se mora navesti kako ih se može pribaviti. U tom slučaju društvo je dužno poslati ih poštom na trošak društva svakom dioničaru koji to zatraži. Vidi i čl. 434. Zakona o tržištu kapitala, Narodne novine br. 88/08, 146/08, 74/09, 54/13, 159/13, 18/15, 110/15.

22 Barbić, Jakša, Sazivanje glavne skupštine i ostvarivanje prava dioničara nakon novele Zakona o trgovačkim društvima iz 2009., Zbornik 48. susreta pravnika, Opatija, 2010., str. 20.

23 Barbić, Jakša, Markovinović, Hrvoje, Parać, Zoran, Petrović, Siniša, Novela Zakona o trgovačkim društvima iz 2009., Novi informator, Zagreb, 2010., str. 45-46., gdje ističu da društvo svojim slobodnim izborom može osigurati jednostavnije i sigurnije zastupanje dioničara. Ističe 
omogućava društvu ne dovesti se u situaciju kada se neće moći utvrditi prava volja dioničara, primjerice kada dioničar nije dao uputu kako glasovati, a opunomoćenici glasuju različito. Valja istaknuti da zakon ne propisuje razloge odbijanja punomoći. Dakle, to će ovisiti o samom društvu. U njemačkom pravu zauzeto je stajalište da se ta odredba primjenjuje i ako dioničar drži više dionica istoga društva. ${ }^{24} \mathrm{~S}$ druge strane, više dioničara može opunomoćiti jednu osobu (njem. Gruppenvertretung). Statutom bi se moglo isključiti zastupanje putem više opunomoćenika. ${ }^{25}$ Novelom ZTD-a iz 2012. godine ${ }^{26}$ propisana je iznimka kada društvo neće moći odbiti prihvatiti jednu ili više punomoći kada je opunomoćeno više osoba. To će biti kada se dionice vode na više računa nematerijaliziranih vrijednosnih papira istog dioničara, a svaka je punomoć dana za zaseban račun nematerijaliziranih vrijednosnih papira istog dioničara ili ako je više punomoći dano po dionicama koje se vode na skrbničkom računu, a dane punomoći ne odnose se na ostvarivanje prava glasa iz više dionica, nego što je zavedeno na skrbničkom računu.

Za davanje punomoći, njezin opoziv i dokazivanje da je dana u odnosu na društvo i u hrvatskom i njemačkom pravu, potreban je pisani oblik. Statutom bi se mogao predvidjeti usmeni oblik. Nužno je istaknuti da kod uvrštenih društava, mora postojati pisani trag o usmeno danoj punomoći jer Direktiva o pravima dioničara uvjetuje da imenovanje opunomoćenika te obavijest o imenovanju i opozivu punomoći moraju biti u pisanom obliku. ${ }^{27}$

Kod društava koja su uvrstila svoje dionice na organizirano tržište kapitala, za prijenos dokaza o tomu da je dana punomoć moguća je elektronička komunikacija. ${ }^{28}$ Dalje ZTD i AktG propisuju obvezu predaje punomoći društvu, koje je zadržava na čuvanju najmanje tri godine. Punomoć u pravilu predaje opunomoćenik prije održavanja glavne skupštine, što može učiniti i neposredno prije njezina početka. ${ }^{29}$

se da bi radi pravne sigurnosti trebalo zauzeti stajalište da se društvo mora opredijeliti prije početka glasovanja. Međutim, naglašavaju da društvo to ne bi moglo učiniti ako je više osoba ovlašteno samo skupno zastupati dioničara na glavnoj skupštini, što se u pravilu u praksi čini s jednom punomoći.

24 Hüffer, Uwe, Aktiengesetz, C. H. Beck, 11. Aufl., 2014., str. 976., Noack, Ulrich, Die Aktionärsrechte-Richtlinie, dostupno na: http://papers.ssrn.com/sol3/papers.cfm?abstract_ id=1138735 (posjećeno 03.12.2016.).

25 Barbić, Jakša, op. cit., str. 36.

26 Zakon o izmjenama i dopunama Zakona o trgovačkim društvima, Narodne novine, br. 111/12.

27 Dakle, ako bi se punomoć davala u usmenom obliku, ona bi se izjavljivala određenim osobama u društvu koje bi mogle o tome napraviti službenu zabilješku koja bi se čuvala u društvu. To bi se trebalo smatrati pisanom potvrdom o usmeno danoj punomoći. Vidjeti više kod Barbić, Jakša, Pravo društava, Knjiga druga, Društva kapitala, Organizator, Zagreb, 2010., str. 1168., Čulinović-Herc, Edita, Hasić, Tea, op. cit., str. 63., gdje ističu da su odredbe Direktive o obliku punomoći regulatorni minimum. Hölters, Wolfgang, Hirschmann, Jörn, Aktiengesetz Kommentar, C. H. Beck, 2. Aufl., 2014., § 134., br. 3., 39.

28 Noack, Ulrich, Hauptversammlung und Internet: Information-Kommunikation-Entscheidung, dostupno na: http://ssrn.com/abstract=646723, str. 22. (posjećeno 22.12.2016.).

29 Jurić, Dionis, Pravno uređenje unutarnjeg korporacijskog upravljanja (corporate governance) u dioničkim društvima u hrvatskom i usporednom pravu društava (doktorska disertacija), Sveučilište u Rijeci, Pravni fakultet, Rijeka, 2005., str. 138., predlaže da bi prikupljanje punomoći trebalo povjeriti neovisnoj trećoj osobi budući da ukoliko se punomoć predaje prije 
U praksi hrvatskih sudova zauzeto je stajalište da nije moguće odrediti rok unutar kojeg je potrebno podnijeti punomoć ili njezinu predaju vezati uz prijavu sudjelovanja na glavnoj skupštini, ako je obveza prijave određena statutom. ${ }^{30}$ Punomoć se može opozvati u svako doba. ${ }^{31}$

Budući da postupak organiziranog prikupljanja punomoći za glasovanje na glavnoj skupštini, prema podatcima iznesenima u njemačkoj literaturi, najčešće provode financijske institucije, potrebno se posebno osvrnuti na odredbe kojima se uređuje ostvarivanje prava glasa putem ovih institucija. ${ }^{32}$ Čak štoviše, kada se u njemačkom pravu govori o organiziranom prikupljanju punomoći za glasovanje na glavnoj skupštini, upućuje se na odredbe $\S 135$. AktG-a kojima se uređuje ostvarivanje prava glasa putem kreditnih odnosno financijskih institucija. ${ }^{33}$

Njemačko i hrvatsko pravo sadrže posebne odredbe o ostvarivanju prava glasa putem kreditnih institucija, ${ }^{34}$ financijskih institucija, udruga dioničara, skrbnika nad dionicama kao i drugih osoba koji na temelju posla koji obavljaju, nude dioničarima da će za njih ostvarivati pravo glasa na glavnoj skupštini (čl. 292. ZTD-a, § 135 AktG-a). Tako se razlikuje položaj kreditne odnosno financijske institucije kada ona glasuje po dionicama koje joj ne pripadaju, ali su u registru upisane na njezino ime, od onog u kojem ostvaruje pravo glasa po dionicama koje joj ne pripadaju i za koje nije upisana u registru dionica kao njihov imatelj. U prvom slučaju, kreditnoj odnosno financijskoj instituciji neće biti potrebna punomoć za glasovanje na glavnoj skupštini, dok će u drugom slučaju moći glasovati na glavnoj skupštini, samo ako je za to opunomoćena. Punomoć se može dati samo jednoj kreditnoj odnosno financijskoj instituciji, koja ju je dužna čuvati tako da se može ispitati. Očitovanje volje kojim se daje punomoć

održavanja glavne skupštine, uprava je u mogućnosti i prije samoga glasovanja saznati kako će se glasovati, što remeti odnos snaga između različitih tijela unutar društva.

30 Presuda Visokog trgovačkog suda RH od 04. lipnja 2002. godine u predmetu br. Pž-1740/02.

31 To može učiniti i kad se u punomoći ili na drugi način odrekne njezina opozivanja. Vidi čl. 316. Zakona o obveznim odnosima, Narodne novine, br. 35/05, 41/08, 125/11, 78/15. Isto stajalište zauzima Barbić, Jakša, Pravo društava, Knjiga druga, Društva kapitala, Svezak I., Dioničko društvo, Organizator, Zagreb, 2013., str. 1221.

32 Za njemačko tržište kapitala karakteristično je ostvarivanje prava glasa preko banaka kao opunomoćenika. Istraživanja pokazuju da banke u svojstvu opunomoćenika ostvaruju preko $60 \%$ prava glasa na glavnim skupštinama uvrštenih društava. Vidi više kod Baums, Theodor, Schmitz, Rainer, Shareholder Voting in Germany, Arbeitspapier Nr. 76, dostupno na: http:// www.jura.uni-frankfurt.de/ifawz1/baums/Bilder_und_Daten/Arbeitspapiere/paper76.pdf, str. 7-8. (posjećeno 03.12.2016.). Schockenhoff, Martin, Proxy Fights - bald auch in Deutschland?, Einwerben von Stimmrechtsvollmachten durch Aktionäre und Verwaltung, Neue Zeitschrift für Gesellschaft, br. 17., 2015., str. 660.

33 Noack, Ulrich, Die organisierte Stimmrechtvertretung auf Hauptversammlungen - insbesondere durch die Gesellschaft, u: Festschrift für Marcus Lutter zum 70. Geburtstag, Verlag Dr. Otto Schmidt, Köln, 2000., str. 1463-1483.

34 Niti hrvatski ZTD, niti njemački AktG ne definiraju kreditnu instituciju, stoga će za hrvatsko pravo biti mjerodavna definicija Zakona o kreditnim institucijama, Narodne novine br. 159/13, 19/15, gdje se u odredbi čl. 3. st. 1. t. 28., vezano za određenje pojma kreditne institucije poziva na čl. 4. st. 1. t. Uredbe (EU) br. 575/2013. Za njemačko pravo mjerodavna je odredba čl. 1. i 2. Kreditwesengesetz in der Fassung der Bekanntmachung vom 9. September 1998, BGB1. I S. 2776, posljednji put izmijenjen čl. 3. Zakona od 30. 06. 2016., BGBl. I S. 1514. 
mora biti potpuno i smije biti povezano samo s očitovanjima volje koja se odnose na korištenje pravom glasa. Dakle, traži se izdavanje samostalne punomoći. ${ }^{35}$

Valja naglasiti da je i u njemačkom i u hrvatskom pravu brisana odredba o ograničenju trajanja punomoći danoj kreditnoj instituciji na 15 mjeseci. ${ }^{36}$ Dakle, punomoć traje do opoziva. Međutim, kreditna odnosno financijska institucija dužna je jednom godišnje jasno upozoriti dioničara na mogućnost svakodobnog opoziva punomoći i promjene opunomoćenika. Ujedno je izričito propisano da se dioničaru mora putem formulara olakšati davanje uputa za glasovanje o odlukama iz pojedinih točaka dnevnog reda, davanje i opoziv punomoći i davanje naloga te njihovu izmjenu (čl. 292. st. 1. ZTD-a, § 135 st. 1. AktG-a).

Kreditna odnosno financijska institucija dužna je glasovati u skladu s dobivenim uputama. Međutim, valja naglasiti da kreditna odnosno financijska institucija ne mora aktivno tražiti uputu o tomu kako glasovati. ${ }^{37}$ Ukoliko dioničar ne dade izričite upute o glasovanju, opća punomoć može dati opunomoćeniku ovlast koristiti pravo glasa samo onako kako je to navedeno u prijedlozima te institucije kako će glasovati ili prijedlozima uprave, odnosno izvršnih direktora, nadzornog odnosno upravnog odbora društva. Ako se ti prijedlozi međusobno razlikuju može glasovati onako kako je to navedeno u prijedlogu nadzornog, odnosno upravnog odbora. Ponudi li kreditna odnosno financijska institucija da će glasovati za neki od navedenih prijedloga, mora istodobno ponuditi i da će proslijediti podloge potrebne za glasovanje.

Odredbom čl. 292. st. 3. ZTD-a i $§ 135$. st. 2. AktG-a izričito je propisano da ako dioničar nije dao upute kreditnoj, odnosno financijskoj instituciji kako glasovati, ona je dužna glasovati u skladu s onime što je predložila, osim ako prema okolnostima smije zaključiti da bi dioničar kad bi znao za stanje stvari odobrio takvo glasovanje. Ujedno kreditna odnosno financijska institucija može odstupiti od vlastitih prijedloga, ali isto tako može odstupiti i od dobivenih uputa. ${ }^{38}$ Zakon izričito propisuje da ukoliko

35 Ako je u punomoći naveden rok trajanja on počinje teći od dana od kada je punomoć izdana. Vidjeti više kod Barbić, Jakša, op. cit., str. 1223.

36 Odredba o ograničenju trajanja punomoći na 15 mjeseci brisana je odredbom čl. 1. Gesetz zur Namensaktie und zur Erleichterung der Stimmrechtsausübung (Namensaktiengesetz NaStraG) vom 18. Januar 2001., BGBl. I S. 123. Ograničenje trajanja punomoći napušteno je i u austrijskom zakonodavstvu.

37 Markovinović, Hrvoje, Tepeš, Nina, Skrbništvo nad vrijednosnim papirima, Zbornik 49. susreta pravnika, Opatija, 2011., str. 114., ističu da se ugovorom pravo na davanje upute ne bi moglo unaprijed isključiti, niti bi se njime moglo predvidjeti da opunomoćenik neće glasovati u skladu s uputama iako su mu dane.

38 Čulinović-Herc, Edita, Hasić, Tea, op. cit., str. 59-60., navode dvojbe oko svrsishodnosti ovog rješenja. Izričito navode "Ako je dioničar izrazio volju kako treba glasovati na skupštini društva, ne vidimo razlog zbog kojeg bi financijska institucija mogla te upute zanemariti, osim ako bi glasovanjem prema dobivenim uputama mogla nastati šteta za opunomoćenog... U svakom bi slučaju pristajalo da opunomoćenik u toj situaciji zahtijeva dodatne upute". Sukladno čl. 765. st. 2. ZOO-a kada nalogoprimac smatra da bi izvršenje naloga po dobivenim uputama bilo od štete za nalogodavca, dužan je skrenuti na to njegovu pozornost i tražiti nove upute. Temeljem čl. 766. st. 1. ZOO-a od dobivenog naloga i uputa nalogoprimac može odstupiti samo sa suglasnošću nalogodavca. Kad mu zbog kratkoće vremena ili iz kakva drugog razloga nije moguće tražiti suglasnost nalogodavca, može odstupiti od naloga i uputa samo ako je po procjeni svih okolnosti mogao osnovano smatrati da to zahtijevaju interesi nalogodavca. 
kreditna odnosno financijska institucija pri glasovanju odstupi od upute koju je dobila od dioničara ili ako te upute nije bilo, od prijedloga što ga je sama objavila, dužna je o tomu izvijestiti dioničara i navesti razloge za taj svoj postupak..$^{39}$

Ako kreditna odnosno financijska institucija želi na temelju dobivene punomoći glasovati za vlastite prijedloge dužna je dioničaru pravodobno dostaviti te prijedloge u pogledu odluka iz pojedinih točaka dnevnog reda. ${ }^{40}$ Ujedno joj je propisana obveza vođenja računa o interesima dioničara te poduzimanja svih organizacijskih priprema da na to ne utječu njezini interesi iz drugih poslovnih područja. Ona mora imenovati jednog člana poslovodstva da nadzire pridržavanje tih obveza kao i uredno korištenje pravom glasa i dokumentaciju o tome. Zajedno s vlastitim prijedlozima, dužna je uputiti na to da će pravo glasa koristiti u skladu sa svojim istaknutim prijedlozima, ako dioničar pravodobno za to ne dade neku drugu uputu.

Zakon propisuje tri situacije u kojima kreditna odnosno financijska institucija treba upozoriti dioničara na eventualno postojanje sukoba interesa. U prvom slučaju, zakonom se izričito propisuje obveza kreditnoj odnosno financijskoj instituciji uputiti na činjenicu ako je član uprave, odnosno izvršni direktor ili njen suradnik član nadzornog odnosno upravnog odbora društva ili član njegove uprave, odnosno izvršni direktor ili suradnik društva i obrnuto (čl. 292. st. 2. ZTD-a, § 135. st. 2. AktG-a). U tom slučaju otvoreno je pitanje koga se smatra suradnikom društva, može li to, primjerice, biti revizor ili odvjetnik koji zastupa društvo.

U druga dva slučaja mora se upozoriti dioničara ako: a) kreditna odnosno financijska institucija ima udio u društvu koji po zakonu mora prijaviti nadležnom nadzornom tijel $\mathrm{u}^{41}$ ili b) je $\mathrm{s}$ društvom u konzorciju koji je u vrijeme posljednjih pet godina preuzeo posljednju emisiju vrijednosnih papira društva. ${ }^{42}$ Dakle, ne traži se da financijska odnosno kreditna institucija obavijesti opunomoćitelja da je primjerice kreditor društva ili je s njim u nekom sličnom poslovnom odnosu.

Valja istaknuti da njemačko i hrvatsko pravo sukob interesa uređuje za slučajeve kada se kao opunomoćenik pojavljuje kreditna ili financijska institucija,

39 U Zakonu nisu navedeni razlozi zbog kojih bi odstupanje od dane upute o glasovanju bilo opravdano.

40 Budući da Zakon govori da te prijedloge mora učiniti dostupnima dioničarima, u hrvatskom se pravu zauzima stajalište da bi ih bilo dovoljno objaviti na internet stranicama kreditne odnosno financijske institucije. Markovinović, Hrvoje, Tepeš, Nina, Ostvarivanje prava glasa po dionicama u skrbništvu, Zbornik radova "Financiranje, upravljanje i restrukturiranje trgovačkih društava u doba recesije“, Pravni fakultet u Rijeci, 2011., str. 367-368.

41 Cilj obavještavanja o držanju kvalificiranog udjela u društvu je upozoriti dioničara da osoba koja djeluje kao njegov opunomoćenik (ili skrbnik) ostvaruje značajan utjecaj na donošenje odluka na skupštini društva temeljem broja glasova koji joj pripadaju. Behnke, Thorsten, Die Stimmrechtsvertretung in Deutschland, Frankreich und England, Neue Zeitschrift für Gesellschaftsrecht, 2000., str. 667.

42 Kreditna odnosno financijska institucija i društvo u tom se slučaju nalaze u odnosu ortaštva. Čulinović-Herc, Edita, Hasić, Tea, op. cit., str. 61-62., zauzimaju stajalište da bi upozorenje dioničaru o postojanju odnosa povezanosti između kreditne odnosno financijske institucije i dioničkog društva čije su dionice u pitanju trebalo uputiti i onda kada između kreditne odnosno financijske institucije i dioničkog društva postoji neki drugi oblik povezanosti, primjerice poduzetnički ugovor. 
udruga dioničara ili osobe koje se na temelju posla koji obavljaju nude dioničarima da će za njih ostvarivati pravo glasa na glavnoj skupštini. Postavlja se pitanje što je s ostalim primjerima sukoba interesa koji su navedeni u čl. 10. Direktive o pravima dioničara, npr. kada je opunomoćenik član uprave društva. U njemačkoj doktrini zauzeto je stajalište da uprava i nadzorni odbor ne mogu glasovati kao opunomoćenici na glavnim skupštinama društva, budući da nemaju pravnu sposobnost. Što se tiče članova tih organa, u njemačkom pravu, ističe se da bi i o njima trebalo zauzeti isto stajalište, kako bi se izbjeglo slučajeve utjecaja uprave na donošenje odluka koje su u nadležnosti glavne skupštine društva u kojima su članovi njegovih organa (tzv. vlastite glavne skupštine) (§ 118. i 119. AktG-a). ${ }^{43}$ Ovdje bi odgovor trebalo pronaći u odredbi $\S$ 136. AktG-a, koji odgovara čl. 293. ZTD-a, prema kojoj nitko ne može ostvarivati pravo glasa za sebe ni za nekoga drugoga kada se odlučuje o tomu hoće li mu se dati razrješnica, o njegovu oslobođenju od neke obveze ili o ostvarenju zahtjeva kojega društvo ima prema njemu. Dakle, riječ je o slučajevima isključenja prava glasa, kada osoba kojoj je isključeno pravo glasa ne bi mogla glasovati niti kao opunomoćenik drugog dioničara. Dalje u zakonu stoji da bi svaki ugovor kojim se dioničar obvezuje da će glasovati po uputama društva, uprave ili nadzornog odnosno upravnog odbora bio ništetan. ${ }^{44}$ Valja spomenuti i isključenje prava glasa članovima uprave, izvršnim direktorima, članovima nadzornog odnosno upravnog odbora kod imenovanja posebnih revizora društva sukladno čl. 298. ZTD-a, odnosno § 142. AktG-a, kada oni također ne mogu glasovati niti u svojstvu opunomoćenika. Ujedno se valja osvrnuti i na odredbu prema kojoj prava glasa po vlastitim dionicama miruju. Ratio tih odredaba je prevenirati zloporabe koje bi mogle nastati ako bi se članovima organa društva omogućilo glasovanje po tim dionicama..$^{45}$

Odgovor se može pronaći i u odredbama AktG-a i ZTD-a kojima se uređuje mogućnost kreditne odnosno financijske institucije glasovati na vlastitoj glavnoj skupštini. Temeljem izričite zakonske odredbe opunomoćena kreditna odnosno financijska institucija, na vlastitoj glavnoj skupštini, smije glasovati na temelju punomoći samo ako je dioničar dao izričitu uputu za glasovanje o odlukama o svakoj točki dnevnog reda. Dakle, to bi bila iznimka od stajališta iznesenoga u njemačkoj doktrini, da članovi uprave ne mogu biti opunomoćenici na glavnim skupštinama

43 Za njemačko pravo vidi Hüffer, Üve, Aktiengesetz Kommentar, 9. Aufl., 2010. § 134. Rn. 26. Lieberam-Schmidt, Sabine, op. cit., str. 33.-34. Behnke, Thorsten, op. cit., str. 671. Bruno, Sabrina, Ruggiero, Eugenio, Public Companies and the Role of Shareholders: National Models Towards Global Integration, Kluwer Law International, 2011., str. 160. Noack, Ulrich, Die organisierte Stimmrechtvertretung auf Hauptversammlungen - insbesondere durch die Gesellschaft, u: Festschrift für Marcus Lutter zum 70. Geburtstag, Verlag Dr. Otto Schmidt, Köln, 2000., str. 1476., gdje se poziva na Lutter, Marcus, Kölner Kommentar zum AktG, § 71b. Hölters, Wolfgang, Hirschmann, Jörn, op. cit., § 134, br. 50.

44 Barbić, Jakša, op. cit., str. 577. ističe da ograničenja iz čl. 293. ZTD-a treba smatrati iznimkama, pa ih se ne bi moglo proširiti i izvan slučajeva koji su tamo propisani, ako ih ZTD posebno ne propisuje.

45 Hanloser, Stefan, Proxy-Voting, Remote-Voting und Online-HV: § 134 III 3 AktG nach dem NaStraG, Neue Zeitschrift für Gesellschaft, br. 8., 2001., str. 356. Lenz, Susanne, Die Gesellschaftsbenannte Stimmrechtsvertretung (Proxy-Voting) in der Hauptversammlung der deutschen Publikums-AG, Duncker \& Humblot, Berlin, 2005., str. 257-259. 
društva u kojima su članovi tih organa ${ }^{46}$ Treba istaknuti da kod glasovanja na vlastitoj glavnoj skupštini ne bi bilo mjesta primjeni odredaba o mogućnosti odstupanja od dobivenih uputa za glasovanje. ${ }^{47}$ Ista se odredba primjenjuje i za glasovanje na skupštini društva u kome kreditna, odnosno financijska institucija neposredno ili posredno sudjeluje u temeljnom kapitalu (njem. Grundkapital) s više od $20 \%$. Iz dikcije ZTD-a kao i AktG-a ne proizlazi da treba držati dionice koje daju pravo glasa, već se uzima u obzir samo sudjelovanje u temeljnom kapitalu, dakle može se raditi i o povlaštenim dionicama bez prava glasa.

Kreditna, odnosno financijska institucija koja na glavnoj skupštini želi na temelju dobivene punomoći glasovati za prijedloge organa društva, dužna je dioničarima društva učiniti dostupnima te prijedloge, ako to već nije učinjeno na neki drugi način (čl. 292. st. 4. ZTD-a, § 135. st. 4. AktG-a). ${ }^{48}$

Kreditna, odnosno financijska institucija smije dati punomoć za zastupanje osobama koje nisu njezini zaposlenici, samo ako to dopušta punomoć koju je dao dioničar (čl. 292. st. 5. ZTD-a, § 135. st. 5. AktG-a).

Kreditna, odnosno financijska institucija smije ostvarivati pravo glasa na temelju dionica koje glase na ime i koje joj ne pripadaju, ali su u registru upisane na njezino ime samo na temelju ovlasti koju za to dobije, primjerice kada djeluje kao skrbnik. ${ }^{49}$

Sukladno odredbi čl. 292. st. 7. ZTD-a na učinak danog glasa ne utječe postupanje protivno odredbama čl. 292. ZTD-a, osim protivno odredbi st. 1. reč. 1. čl. 292. ZTD-a. Navedenu bi odredbu trebalo tumačiti na sljedeći način: a) odluka glavne skupštine može se pobijati ako je na glavnoj skupštini glasovala kreditna, odnosno financijska

46 Henssler, Martin, Strohn, Lutz, Liebscher, Thomas, Aktiengesetz Kommentar, Gesellschaftrecht, Verlag C.H. Beck München, 2. Auflage, 2014., § 134, br. 10.

47 Isto stajalište zauzimaju i Čulinović-Herc, Edita, Hasić, Tea, op. cit., str. 62. Zetzsche, Dirk, Shareholder Interaction Preceding Shareholder Meetings of Public Corporations - A Six Country Comparison, European Corporate \& Finance Law Review - ECFR 2:1, 105, 2005. dostupno na: http://ssrn.com/abstract=648982, str. 23. (posjećeno 04.12.2016.), gdje se poziva na vladajuće mišljenje u njemačkoj doktrini da će se, ukoliko u punomoći nisu dane upute kako glasovati o pojedinom pitanju, smatrati da se opunomoćenik suzdržao od glasovanja.

48 Markovinović, Hrvoje, Tepeš, Nina, Skrbništvo nad vrijednosnim papirima, cit., str. 118-119., ističu da se u ovom slučaju primjenjuje ne samo odredba čl. 292. st. 4. ZTD-a, već i određeni dijelovi čl. 292. st. 2. i 3. ZTD-a. Tako se ovo posebno odnosi na a) slučaj kada čl. 292. st. 2. ZTD-a predviđa da dioničar može, učini li to pravodobno, dati neku drugu uputu koja bi bila različita od prijedloga organa društva, u kojem bi slučaju opunomoćenik bio vezan tako dobivenom uputom, b) slučaj iz prve rečenice čl. 292. st. 3. ZTD-a, koji propisuje obvezu skrbnika da pravo glasa koristi u skladu s onim što je predložio, osim ako prema okolnostima smije zaključiti da bi zakoniti imatelj, kad bi znao za stanje stvari, odobrio odstupanje od predloženoga, c) slučaj iz druge rečenice čl. 292. st. 3. ZTD-a koji u slučaju eventualnog odstupanja predviđa obvezu skrbnika da o tome izvijesti zakonitog imatelja dionice i navede razloge za taj svoj postupak i d) slučaj iz treće rečenice čl. 292. st. 3. ZTD-a koji predviđa da ograničenje prema kojemu skrbnik na vlastitoj glavnoj skupštini pravo glasa smije koristiti samo ako je zakoniti imatelj dionice dao izričitu uputu za glasovanje o odlukama o svakoj točki dnevnog reda.

49 Barbić, Jakša, Markovinović, Hrvoje, Parać, Zoran, Petrović, Siniša, op. cit., str. 49., gdje naglašavaju da to proizlazi iz odnosa dioničara i njegova povjerenika, pa i povredu tog pravila valja ocjenjivati kao povredu njihova povjereničkog odnosa. Društvo u tom slučaju dioničarom smatra povjerenika. 
institucija koja nije upisana u registar dionica i koja nije imala punomoć za glasovanje i b) odluka glavne skupštine ne može se pobijati ako je na glavnoj skupštini glasovala kreditna, odnosno financijska institucija koja je, iako upisana u registar dionica, pravo glasa ostvarivala, a da za to nije imala ovlast osobe čije su dionice u skrbništvu. ${ }^{50}$ Isto tako odluka se ne bi mogla pobijati ako bi kreditna odnosno financijska institucija glasovala protivno dobivenim uputama.

Punomoć za glasovanje na glavnoj skupštini može se dati udruzi dioničara. Upravo je ova odredba bitna za organizirano prikupljanje punomoći za glasovanje na glavnoj skupštini, kojega, pored financijskih institucija, najčešće provode udruge dioničara, budući da članstvo u udruzi dioničara ne daje ovlast za zastupanje toj udruzi, već je potrebno davanje punomoći. ${ }^{51} \mathrm{I}$ u njemačkom i u hrvatskom pravu izričito je propisano da se odredbe o ostvarivanju prava glasa putem kreditnih odnosno financijskih institucija na odgovarajući način primjenjuju i na udruge dioničara, ali isto tako i na osobe koje se na temelju posla koji obavljaju nude dioničarima da će za njih ostvarivati pravo glasa na glavnoj skupštini društva. Dakle i oni su obuhvaćeni poljem primjene čl. 292. ZTD-a, odnosno $\S 135$. AktG-a. Te se odredbe ne primjenjuju na one koji žele ostvarivati pravo glasa za dioničara ako su njegovi zakonski zastupnici, bračni ili izvanbračni drugovi ili su s njime u krvnom ili tazbinskom srodstvu do četvrtog stupnja srodstva.

Vezano za naknadu štete, u njemačkom je pravu odredbom § 135. st. 9. AktG-a, a u hrvatskom pravu odredbom čl. 292. st. 9. ZTD-a izričito propisano da se obveza kreditne institucije naknaditi štetu nastalu zbog povrede ovih obveza, ne može unaprijed isključiti ni ograničiti. U njemačkoj se doktrini zaključuje da ovom zakonskom odredbom nisu obuhvaćene udruge dioničara, što znači da bi one mogle unaprijed isključiti ili ograničiti svoju odgovornost. ${ }^{52}$

Postupanje protivno odredbama o glasovanju putem opunomoćenika u njemačkom i hrvatskom pravu sankcionira se kao prekršaj (čl. 631. ZTD-a, § 405. AktG-a).

\subsubsection{Države članice koje su usvojile posebne odredbe o organiziranom} prikupljanju punomoći za glasovanje na glavnoj skupštini

Kao primjer država članica EU-a koje su usvojile posebne odredbe o organiziranom prikupljanju punomoći za glasovanje na glavnoj skupštini, u radu se obrađuju odredbe slovenskog, francuskog i talijanskog prava.

U slovenskom pravu glasovanje putem opunomoćenika izričito je dopušteno temeljem čl. 308. st. 6. Zakona o gospodarskih družbah ${ }^{53}$ (dalje u tekstu: ZGD). Zakonom se propisuje oblik punomoći i obveza njene predaje društvu. Tako je

50 Markovinović, Hrvoje, Tepeš, Nina, op. cit., str. 122.

51 Za njemačko pravo vidjeti više kod Noack, Ulrich, Die organisierte Stimmrechtvertretung auf Hauptversammlungen - insbesondere durch die Gesellschaft, u: Festschrift für Marcus Lutter zum 70. Geburtstag, Verlag Dr. Otto Schmidt, Köln, 2000., str. 1468.

52 Hüffer, Uwe, Aktiengesetz, C. H. Beck, 11. Aufl., 2014., str. 998.

53 Zakon o gospodarskih družbah, Uradni list RS, br. 33/11, 91/11, 32/12, 57/12, 44/13, 82/13, $55 / 15$. 
propisano da punomoć mora biti u pisanom obliku i da se treba predati društvu na čuvanje. Međutim, za razliku od hrvatskoga i njemačkog prava, slovenski ZGD ne propisuje rok u kojem je društvo dužno čuvati predanu punomoć. Vezano za svojstva koja mora imati opunomoćenik slovensko je zakonodavstvo usklađeno s odredbama Direktive o pravima dioničara, propisujući da opunomoćenik može biti svaka poslovno sposobna fizička ili pravna osoba. Ta će osoba na glavnoj skupštini uživati ista upravljačka prava kao i dioničar kojega zastupa. Dioničarima društva koje je uvrstilo svoje dionice na organizirano tržište kapitala dana je mogućnost imenovati opunomoćenika uporabom elektroničkih sredstava (čl. 308. st. 7. ZGD-a) te na isti način opozvati tako danu punomoć.

Odredbom čl. 308.a ZGD-a propisana je obveza osobi koja neodređenom broju dioničara ponudi zastupanje na glavnoj skupštini, otkriti postojanje okolnosti koje dovode do sukoba interesa. ${ }^{54}$ Iznimno, to neće biti dužna učiniti osoba koja na skupštini ne zastupa više od deset dioničara i više od $1 \%$ temeljnoga kapitala društva.

Glasovanje putem financijskih i drugih institucija u slovenskom je zakonodavstvu uređeno čl. 309. ZGD-a. Financijska institucija može ostvarivati pravo glasa samo na temelju dobivene punomoći u pisanom obliku. Punomoć se može dati za razdoblje od najduže 15 mjeseci te se može u svakom trenutku opozvati. Financijska institucija smije dati punomoć za zastupanje osobama koje nisu njezini zaposlenici, samo ako je to izričito dopušteno u punomoći koju je dao dioničar.

Sukladno odredbi čl. 309. st. 5. ZGD-a, ako dioničar ne dade upute za glasovanje financijskoj instituciji, ona je dužna glasovati u skladu s onime što je predložila, osim ako prema okolnostima smije zaključiti da bi dioničar, kad bi znao za stanje stvari, odobrio drukčije glasovanje. Ako financijska institucija glasuje protivno uputi koju je dobila od dioničara, o tomu ga mora obavijestiti i navesti mu razloge za takvo glasovanje.

Svoju odgovornost za povredu odredaba o ostvarivanju prava glasa dioničara na glavnoj skupštini kao opunomoćenik, financijska institucija ne može unaprijed isključiti niti ograničiti.

U slovenskoj se doktrini ističe da je najučinkovitiji način zaštite manjinskih dioničara od zloporabe prava glasa od strane institucionalnih ulagatelja, tako da se propiše da bez podrobnih uputa dioničara oni ne mogu glasovati, te da se smatra da se ako ne postoje upute o glasovanju, dioničar suzdržao od glasovanja. ${ }^{55}$

Posebnost je slovenskoga zakonodavstva, izričito uređenje organiziranog prikupljanja punomoći za glasovanje na glavnoj skupštini. Organizirano prikupljanje punomoći za glasovanje na glavnoj skupštini uređeno je odredbama dvaju zakona,

54 Zakon propisuje pretpostavke da postoji sukob interesa ako je opunomoćenik: a) većinski dioničar društva ili osoba koju on kontrolira, b) član organa koji vodi ili nadzire vođenje poslova društva ili većinskog dioničara ili osobe koju on kontrolira, c) zaposlenik ili revizor društva, većinskoga dioničara ili osobe koju on kontrolira ili d) član uže obitelji fizičkih osoba navedenih u prijašnjim stavcima. Slovenski zakonodavac u čl. 308.a st. 3. ZGD-a izričito propisuje koga se smatra članom uže obitelji.

55 Bratina, Borut, Uresničevanje glasovalne pravice in pooblaščenci delničarjev, Sedemnajsto posvetovanje o aktualni problematiki s področja gospodarskega prava, Gospodarski subjekti na trgu - novosti in aktualna vprašanja gospodarskega prava, Portorož, 2009., str. 27. 
ZGD-a i Zakona o preuzimanju dioničkih društava ${ }^{56}$ (dalje u tekstu: ZPre). Pod organiziranim prikupljanjem punomoći (slo. organizirano zbiranje pooblastil) podrazumijeva se svako prikupljanje punomoći koje je usmjereno prema više od 50 dioničara koji drže dionice s pravom glasa (čl. 310. ZGD-a i čl. 61. st. 2. ZPre). Financijske institucije, udruge dioničara i druge osobe koje namjeravaju na glavnoj skupštini ostvarivati pravo glasa na temelju punomoći prikupljenih u postupku organiziranog prikupljanja punomoći, moraju biti opunomoćene u pisanom obliku (čl. 310. st. 1. ZGD-a). Zakon izričito propisuje da tako dana punomoć vrijedi samo za jednu skupštinu te mora sadržavati prijedloge odluka, prijedlog punomoćnika za glasovanje o stavljenim prijedlozima, poziv dioničaru dati upute za glasovanje s upozorenjem da ako on ne dade upute da će opunomoćenik glasovati u skladu sa svojim prijedlozima koji moraju biti obrazloženi u punomoći kao i upozorenjem da dioničar može punomoć opozvati u svakom trenutku. Dalje se slovenskom ministru gospodarstva daje ovlast propisati obrazac punomoći za glasovanje o pojedinim pitanjima na glavnoj skupštini (čl. 310. st. 4. ZGD-a). Ako bi punomoći bile prikupljene protivno propisanim odredbama, takve bi punomoći, temeljem odredbe čl. 310. st. 5 . ZGD-a, bile ništetne. Dakle, riječ je o kogentnim odredbama.

ZPre u čl. 8. propisuje da osoba ili osobe koje namjeravaju na glavnoj skupštini ostvarivati pravo glasa na temelju punomoći prikupljenih u postupku organiziranog prikupljanja punomoći, moraju o toj namjeri, razlozima kao i načinu prikupljanja punomoći prethodno obavijestiti Agenciju za trg vrednostnih papirjev (ATVP) te obavijesti priložiti primjerak punomoći. Postupanje protivno navedenoj odredbi dovodi do pretpostavke da je prikupljanjem punomoći prikriven sporazum o zajedničkom djelovanju u postupku preuzimanja.

U postupku uređenja instituta organiziranog prikupljanja punomoći za glasovanje na glavnoj skupštini u slovenskom zakonodavstvu, udruge dioničara su isticale da će tako stroga i formalna pravila biti zapreka za učinkovito zastupanje manjinskih dioničara od strane udruga dioničara. ${ }^{57}$ Argument koji se isticao u prilog tom stajalištu bio je da je prikupljanje punomoći povezano s visokim troškovima, a što je još više naglašeno odredbom kojom se ograničava valjanost tako dane punomoći na jednu glavnu skupštinu. ${ }^{58}$

Glasovanje putem opunomoćenika na glavnoj skupštini društva u francuskom pravu uređeno je odredbom čl. L225-106 Trgovačkog zakonika (Code de commerce). Izričito je propisano da dioničar može dati punomoć drugom dioničaru ili svojem bračnom drugu. Prenošenjem Direktive o pravima dioničara u francusko zakonodavstvo, odredba je izmijenjena tako da je proširen krug osoba kojima se može

56 Zakon o prevzemih, Uradni list, br. 79/06, 67/07, 01/08, 68/08, 35/11, 105/11, 10/12, 38/12.

57 U Sloveniji je organizirano Vseslovensko združenje malih delničarjev - VZMD koje zastupa manjinske dioničare na glavnim skupštinama većih slovenskih uvrštenih društava. O stajalištima VZMD u pogledu predloženih izmjena ZGD vidjeti više na: http://www.vzmd.si/novice/ soglasni-gospodarski-odbor-dz-rs-vzmd-naj-sodeluje-pri-pripravi-sprememb-zakonodaje (posjećeno 12.12.2016.).

58 Ujedno se u slovenskoj doktrini ističe da se interesi manjinskih dioničara mogu zaštititi na učinkovitiji način od propisivanja valjanosti punomoći za samo jednu glavnu skupštinu. Vidi Bratina, Borut, op. cit., str. 25. 
dati punomoć za glasovanje na glavnoj skupštini. Tako je dioničarima dana mogućnost dati punomoć drugoj osobi, dakle ne isključivo dioničaru, ali samo pod sljedećim uvjetima: 1. ako se radi o dionicama društva koje su uvrštene na uređeno tržište kapitala, 2. ako se radi o dionicama koje su uvrštene na multilateralnu trgovinsku platformu na koju se primjenjuju propisi o zaštiti ulagatelja od insider tradinga, manipulacije cijenom i širenja lažnih informacija u skladu s aktima nacionalnoga regulatornog tijela (L'Autorité des marchés financiers, dalje u tekstu: AMF) ${ }^{59} \mathrm{U}$ tim slučajevima, dakle kada opunomoćenik nije dioničar društva ili bračni drug, on je dužan upozoriti dioničara o postojanju sukoba interesa, što je detaljno uređeno u čl. L225-106-1 Trgovačkog zakonika ${ }^{60}$ Kada se pojavi neki od slučajeva sukoba interesa, opunomoćenik je dužan o tomu bez odgađanja obavijestiti dioničara koji mu je dao punomoć. Ukoliko dioničar izričito ne potvrdi punomoć, to dovodi do prestanka punomoći, o čemu je opunomoćenik dužan obavijestiti društvo.

Ujedno, dioničar treba voditi računa o tomu da je opunomoćenik ovlašten glasovati za odluke koje se donose na glavnoj skupštini. Ukoliko on nije ovlašten glasovati kao dioničar, dakle kada mu je isključeno pravo glasa na glavnoj skupštini, neće moći glasovati niti u svojstvu opunomoćenika (čl. L225-10 u svezi s čl. L225147 Trgovačkog zakonika).

Punomoć se daje u pisanom obliku i dostavlja se društvu na čuvanje (čl. L225106-1 st. 6. i 7. i čl. R225-82-2 Trgovačkog zakonika). Prenošenjem Direktive o pravima dioničara u francusko pravo, društvima koja su uvrstila svoje dionice na organizirano tržište kapitala dana je mogućnost dostavljanja obavijesti o imenovanju i opozivu opunomoćenika elektroničkim putem (čl. R225-79 st. 6. Trgovačkog zakonika).

Sukladno francuskom pravu, statutom se može odrediti najveći broj glasova koje jedna osoba može imati bilo da nastupa osobno, bilo kao opunomoćenik. Dakle, moguće je ograničenje glasačke snage.

Dioničar može dati punomoć bez naznake opunomoćenika (franc. pouvoir en

59 Radi poticanja sudjelovanja dioničara u donošenju odluka u društvu u francuskom pravu je 2010. godine Ordonansom br. 2010-1511 od 09. prosinca 2010. godine, a koje se primjenjuju od 1. siječnja 2011. godine, dana je mogućnost dioničarima da ih na glavnoj skupštini društava koja su uvrstila svoje dionice na NYSE Euronext Paris ili na Alternext, zastupa opunomoćenik. Do 2010. godine opunomoćenik je mogla biti osoba koja drži barem jednu dionicu društva, dakle samo dioničar društva. Buhart, Jacques, Lafont, Nicolas, u: Kawamura, Akira, Mori, Anderson, Tomotsune (edt.), Corporate Governance, Jurisdictional Comparisons, First Edition, 2013., str. 84. Heckel, Gilles, Larcena, Antoine, Panorama des aménagements apportés aux droits des actionnaires de sociétés cotées suite à la transposition de la directive 2007/36/CE du 11 juillet 2007, Revue de Droit bancaire et financier, br. 5., 2011., str. 20., Gérard Notté, Exercice de certains droits des actionnaires de sociétés cotées (Ord. n 2010-1511, 9 déc. 2010), La Semaine Juridique Entreprise et Affaires, br. 50., 2010.

60 Sukladno odredbi čl. L225-106-1 Trgovačkog zakonika sukob interesa postoji kada je opunomoćenik dioničar koji kontrolira društvo ili je drugi subjekt kojega kontrolira takav dioničar, član upravnog, upravljačkog ili nadzornog tijela društva ili dioničara koji kontrolira društvo ili subjekta kojega kontrolira takav dioničar, zaposlenik društva ili dioničara koji kontrolira društvo ili subjekta kojega kontrolira takav dioničar. Takva se informacija mora dati i ako je opunomoćenik u obiteljskoj vezi s dioničarom, kao i fizičkim osobama iz navedenih slučajeva obuhvaćenih odredbom čl. L225-106-1 Trgovačkog zakonika. 
blanc), kada će se glasovanje opunomoćenika smatrati kao glas koji ide u prilog prijedloga odluka uprave društva (čl. L225-106 Trgovačkog zakonika).

Sukladno odredbi čl. L225-120 francuskoga Trgovačkog zakonika dioničar može svoje pravo glasa ostvarivati putem udruga dioničara. Izričito je propisano da u dioničkim društvima čije su dionice uvrštene na uređena tržišta kapitala, dioničari čije su dionice uvrštene najmanje dvije godine i koji zajedno drže dionice koje daju najmanje $5 \%$ prava glasa mogu osnivati udruge radi ostvarenja svojih interesa u dioničkim društvima. ${ }^{61}$

Odredbom čl. L225-106-2 francuskoga Trgovačkog zakonika uređuje se organizirano prikupljanje punomoći za glasovanje na glavnoj skupštini. Izričito je propisano da svatko tko aktivno prikuplja punomoći za glasovanje (franc. sollicitation active de mandats), na način da izravno ili neizravno predlaže jednom ili više dioničarima, da mu daju punomoći za zastupanje na glavnoj skupštini, dužan je na svojim internetskim stranicama objaviti "politiku glasovanja" (franc. politique de vote). Sukladno odredbi čl. R225-82-3 Trgovačkog zakonika, u tom dokumentu objavljuje namjeru kako će glasovati za pojedine točke dnevnoga reda, što se onda primjenjuje na sve punomoći za koje nije dana uputa za glasovanje na glavnoj skupštini. Ujedno, osoba koja prikuplja punomoći mora obavijestiti dioničare koji mu daju punomoć o svakoj činjenici i okolnostima koje bi mogle dovesti do sukoba interesa, primjerice da je on direktor ili zaposlenik društva. Punomoć se može dati za jednu glavnu skupštinu. Međutim, može biti dana i za dvije glavne skupštine, redovitu i izvanrednu, pod uvjetom da se održavaju isti dan ili u razdoblju od petnaest dana (čl. R225-79 Trgovačkog zakonika). ${ }^{62}$

Posebnost je francuskoga prava u propisivanju sankcija ukoliko osoba koja prikuplja punomoći ne postupi u skladu s odredbama Trgovačkog zakonika. U tom slučaju, trgovački sud na području kojeg se nalazi sjedište društva može joj, na zahtjev opunomoćitelja i za razdoblje od najdulje tri godine, oduzeti pravo na zastupanje na skupštinama tog trgovačkog društva. Sud ujedno može donijeti odluku o javnoj objavi izrečenih mjera (čl. L225-106-3 Trgovačkog zakonika). Takvu odluku sud može donijeti i na zahtjev samoga društva.

Mogućnost davanja punomoći za glasovanje na glavnoj skupštini u talijanskom je pravu propisana odredbama čl. 2372. Građanskoga zakonika (tal. Rappresentanza nell'assemblea).$^{63}$ Izričito je propisano da punomoć mora biti u pisanom obliku i mora se predati društvu na čuvanje. ${ }^{64}$ Kod društava koja djeluju na tržištu rizičnog kapitala

61 Što je temeljni kapital društva viši, to je potrebni udio u pravu glasa manji za osnivanje udruge dioničara, te iznosi $4 \%$ ako je temeljni kapital između 750.000-4.500.000 eura, $3 \%$ između 4.500.000 - 7.500.000 eura, $2 \%$ između 7.500.000-15.000.000 eura i $1 \%$ preko 15.000 .000 eura.

62 Le Nabasque, Hervé, Droits des actionnaires des sociétés cotées, Revue de Droit bancaire et financier, br. 1., 2011., par. 29. Buhart, Jacques, Lafont, Nicolas, op. cit., str. 91.

63 Vidi više kod Ferrucci, Annamaria, Ferrentino, Carmine, Società di capitali, società cooperative e mutue assicuratrici, Seconda edizione, Tomo I, Giuffrè Editore, 2012., str. 580-581.

64 Di Amato, Sergio, Muscolo, Gabriella, Sciumbata, Gabriele, Le assemble nelle S.p.A., Giuffrè Editore, 2011., str. 100., ističe da se, u tom slučaju, statutom ne bi mogao odrediti drukčiji oblik davanja punomoći. 
(tal. società che fanno ricorso al mercato del capitale di rischio) punomoć može biti dana samo za jednu skupštinu, koja može vrijediti i za sljedeće sazive te iste skupštine, osim ako je dana opća punomoć (tal. procura generale) ili ako je društvo, udruga, zaklada ili drugo kolektivno tijelo ili institucija (tal. società, associazione, fondazione o altro ente collettivo o istituzione) dalo punomoć svome zaposleniku. Ukoliko bi punomoć bila dana društvu, udruzi, zakladi ili drugom kolektivnom tijelu ili instituciji ono može delegirati na glavnu skupštinu samo jednog zaposlenika ili suradnika (čl. 2372. st. 4. Građanskog zakonika). Dana punomoć se može u svako doba opozvati.

Sukladno talijanskom pravu punomoć se ne može dati članovima organa društva, zaposlenicima društva, društvu koje nad njime ostvaruje kontrolu kao niti članovima organa i zaposlenicima toga društva (čl. 2372. st. 5. Građanskog zakonika).

Jedna osoba na glavnoj skupštini ne može zastupati više od dvadeset dioničara, odnosno ako je riječ o društvima koja djeluju na tržištu rizičnog kapitala, više od pedeset dioničara ako temeljni kapital društva nije viši od pet milijuna eura, više od 100 dioničara ako je temeljni kapital društva između pet milijuna eura i 25 milijuna eura te više od 200 dioničara, ako društvo ima temeljni kapital viši od 25 milijuna eura (čl. 2372. st. 6. Građanskog zakonika).

Odredbe čl. 2372. st. 5. i 6. Građanskog zakonika kojima se uređuje ograničenje odnosno zabrana davanja punomoći članovima organa društva kao i društva koje nad njim ostvaruje kontrolu kao i njihovim zaposlenicima te broj dioničara koje opunomoćenik može zastupati, ne primjenjuju se na društva koja su uvrstila svoje dionice na organizirano tržište kapitala. Dakle, pored odredaba čl. 2372. st. 1.-4. Građanskog zakonika na imenovanje opunomoćenika za glasovanje na glavnoj skupštini društva koje je uvrstilo svoje dionice na organizirano tržište kapitala, primjenjuju se i odredbe Testo Unico della Finanza (dalje u tekstu: TUF) ${ }^{65} \mathrm{U}$ čl. 135-novies TUF-a izričito je propisano pravo dioničara imenovati opunomoćenika za glasovanje na glavnoj skupštini. Pritom dioničar može imenovati različite opunomoćenike za glasovanje po dionicama koje su zabilježene na različitim računima, koji se koriste za evidentiranje transakcija financijskim instrumentima, pod uvjetom da je učinjeno valjano obavještavanje u skladu s odredbama čl. 83-sexies TUF-a. Obavijest da je dana punomoć može biti učinjena u elektroničkom obliku.

Odredbom čl. 135-decies TUF-a uređuje se postojanje sukoba interesa te se izričito nameće obveza opunomoćeniku obavijestiti dioničara o postojanju okolnosti koje dovode do sukoba interesa te, u tom slučaju, dobiti upute za glasovanje za svaku točku dnevnoga reda na glavnoj skupštini. Sukob interesa postoji kada je opunomoćenik: a) osoba koja samostalno ili zajednički s drugim osobama ostvaruje kontrolu nad društvom ili njega kontrolira to društvo, b) povezan s društvom ili ostvaruje prevladavajući utjecaj nad društvom ili društvo ostvaruje prevladavajući utjecaj nad opunomoćenikom, c) član uprave društva ili osoba navedenih u t. a i b, d) zaposlenik ili revizor društva ili osoba navedenih u t. a, e) bračni drug, bliski srodnik do četvrtog koljena osobama navedenima u t. a do c, f) povezan s društvom ili osobama

65 Decreto Legislativo 24 febbraio 1998, n. 58, "Testo unico delle disposizioni in materia di intermediazione finanziaria, ai sensi degli articoli 8 e 21 della legge 6 febbraio 1996, n. 52", Gazzetta Ufficiale n. 71 del 26 marzo 1998 - Supplemento Ordinario n. 52. 
navedenima u t. a, b, c i e odnosima ili financijskom prirodom koja kompromitira njegovu neovisnost.

Dakle, vezano uz davanje punomoći za glasovanje članovima organa društva, valja naglasiti da se na talijanska uvrštena društva ne primjenjuje odredba čl. 2372. st. 5. Građanskog zakonika, koja zabranjuje davanje punomoći članovima organa društva. Stoga se punomoć može dati članovima organa uvrštenog društva, ali uz poštovanje odredaba o postojanju sukoba interesa, što znači da će oni moći glasovati u svojstvu opunomoćenika, pod uvjetom da su dobili uputu za glasovanje. ${ }^{66}$ Valja istaknuti odredbu čl. 2373. Građanskog zakonika temeljem koje članovi uprave ne mogu glasovati o pitanjima koja se tiču njihove odgovornosti. Ujedno im je isključeno pravo glasa kod izbora i opoziva članova nadzornog odbora. Ovdje se postavlja pitanje mogu li oni glasovati o tim pitanjima u svojstvu opunomoćenika kada se radi o uvrštenim društvima? Zauzeto je stajalište da u ovim slučajevima oni ne bi mogli glasovati u svojstvu opunomoćenika, niti bi mogli provoditi postupak organiziranog prikupljanja punomoći za glasovanje na glavnoj skupštini na kojoj se odlučuje o njima. ${ }^{67}$

Prijenosom Direktive o pravima dioničara u talijansko zakonodavstvo ${ }^{68}$ propisana je nova odredba, kojom društva koja su uvrstila svoje dionice na organizirano tržište kapitala mogu imenovati predstavnika za pojedinu glavnu skupštinu, kojemu dioničari mogu, najkasnije dva trgovinska dana prije održavanja glavne skupštine, dati punomoć za zastupanje na glavnoj skupštini s uputama kako glasovati za sve ili pojedine točke dnevnoga reda (čl. 135-undecies st. 1. TUF-a). Društvo bi statutom moglo isključiti ovu mogućnost. ${ }^{69}$ Punomoć je valjana samo za one točke dnevnoga reda za koje su dane upute za glasovanje (čl. 135.-undecies st. 1. TUF-a). Ujedno, punomoć se može dati samo na obrascu kojega je propisao CONSOB. Međutim, i pored prava na "posebnog predstavnika", dioničari imaju pravo imenovati osobu koja će ih zastupati na glavnoj skupštini. ${ }^{70}$

Organizirano prikupljanje punomoći za glasovanje na glavnoj skupštini u

66 Abriani, N. et. al., Diritto delle società, Quinta edizione, Giuffrè Editore, 2012., str. 199.

67 Ricciardiello, Edgardo, La nouova disciplina in material di sollecitazione delle deleghe di voto: inizia la stagione italiana dei proxy fights?, Giurisprudenza Commerciale, br. 1., 2012., str. 167. Vidi i De Pra, Alberto, Deliberazione negativa votata in conflitto d'interessi e divieto di voto del socio-amministratore, Giurisprudenza Commerciale, br. 5, 2010., str. 922.

68 Direktiva o pravima dioničara prenesena je u talijansko pravo 2010. godine odredbama Decreto Legislativo 27 gennaio 2010, n. 27 “Attuazione della direttiva 2007/36/CE, relativa all'esercizio di alcuni diritti degli azionisti di societa’ quotate”, Gazzetta Ufficiale del 5 marzo 2010, n. 53 Supplemento Ordinario n. 43.

69 La nuova disciplina del funzionamento dell'assemblea delle società quotate, Circolare Assonime n. 14/2011, Rivista delle Società, br. 2-3, 2011., str. 527. Eckbo, B. Espen, Paone, Giulia, Reforming Share-Voting Systems: The Case of Italy, Tuck School of Business Working Paper No. 2011-93, 2011., str. 15.

70 Bruno, Sabrina, Legal rules, Shareholders and Corporate Governance. The European Shareholder Rights' Directive and its impact on Corporate Governance of Italian Listed Companies: The Telecom S.p.A. case, Corporate Ownership \& Control, vol. 12., br. 2., 2015., str. 402., ističe da je 2013. godine 95,8 \% dioničara glasovalo putem opunomoćenika, dok je svega $4,2 \%$ glasovalo osobno. 
talijanskom je pravu uređeno čl. 136.-144. TUF-a (tal. Sollecitazione di deleghe). Da bi postupak prikupljanja punomoći bio obuhvaćen tom odredbom potrebno je da je zahtjev upućen prema više od 200 dioničara te da sadrži prijedloge za glasovanje ili preporuke, izjave ili druge pokazatelje kojima se može utjecati na ishod glasovanja (čl. 136. st. 1(b) TUF-a). ${ }^{71}$ Svaka osoba koja namjerava provesti postupak organiziranog prikupljanja punomoći za glasovanje na glavnoj skupštini dužna je o tomu obavijestiti izdavatelja, koji je dužan tu obavijest, bez odgode, objaviti na svojim internetskim stranicama, CONSOB, burzu na kojoj su uvrštene dionice društva i središnji depozitorij. Na postupak organiziranog prikupljanja punomoći primjenjuju se i odredbe o imenovanju punomoćnika (čl. 135-novies TUF-a) te o sukobu interesa (čl. 135-decies TUF-a). Dalje u zakonu stoji da ako bi statut sadržavao odredbu koja na bilo koji način ograničava zastupanje dioničara na glavnoj skupštini, takva se odredba neće primjenjivati na punomoći stečene $u$ tom postupku.

Specifičnost je talijanskog prava što postupak organiziranog prikupljanja punomoći provodi promotor diseminacijom prospekta (tal. prospetto) i obrasca punomoći (tal. modulo di delega).

Na glavnoj skupštini pravo glasa, na temelju prikupljenih punomoći, ostvaruje osoba koja je provela postupak prikupljanja punomoći - promotor (čl. 138. st. 2. TUF-a). Nju mogu opozvati samo osobe koje su izričito naznačene u prospektu i obrascu punomoći. U prospektu moraju biti naznačeni, između ostaloga, prijedlozi odluka za koje se traže punomoći kao i važni razlozi, podaci o osobi koja prikuplja punomoći i društvu, informacije o eventualnoj naknadi koju isplaćuje osoba koja prikuplja punomoći, u skladu s obrascem kojega je propisao CONSOB.

Posebno je uređeno stjecanje punomoći od strane udruga dioničara. Izričito je propisano da se neće raditi o organiziranom prikupljanju punomoći u smislu odredbe čl. 136. st. 1(b) TUF-a, ukoliko udruga postupak prikupljanja punomoći provodi radi stjecanja punomoći od dioničara koji su njeni članovi, ako: (i) su osnovani na temelju javnobilježničke isprave, (ii) ne obavljaju poslovnu aktivnost drukčiju od one koja služi svrsi udruge i (iii) sastoje se od najmanje 50 fizičkih osoba, pod uvjetom da svaka od njih drži manje od 0,1 \% dionica koje daju pravo glasa (čl. 141. TUF-a). ${ }^{72}$

Odredbom čl. 142. st. 1. TUF-a izričito je propisano da opunomoćitelj mora potpisati punomoć te je može opozvati u svako doba. Punomoć se može dati za samo jednu sazvanu glavnu skupštinu (tal. soltanto per singole assemblee già convocate). Može se dati i samo za neke prijedloge, odnosno točke dnevnoga reda glavne

71 Prijenosom Direktive o pravima dioničara u uvrštenim društvima u talijansko pravo više se ne traži da osoba koja prikuplja punomoći za glasovanje na glavnoj skupštini drži $1 \%$ temeljnoga kapitala društva. Ujedno osoba koja prikuplja punomoći ne mora više imenovati financijskoga posrednika. Navedene su izmjene učinjene radi pojednostavljenja uvjeta za glasovanje putem opunomoćenika. Vidi više kod New Tools to Encourage Shareholder Participation in the Life of Italian Listed Companies, dostupno na: http:/www.shearman.com/ /media/Files/ NewsInsights/Publications/2010/04/New-Tools-to-Encourage-Shareholder-Participation_/ Files/View-full-memo-New-Tools-to-Encourage-Shareholde_/FileAttachment/ EC042110NewToolstoEncourageShareholderParticipat_.pdf (posjećeno 15. 12. 2016.).

72 Visco, Claudio, Pucci, Ernesto u: Kawamura, Akira, Mori, Anderson, Tomotsune (edt.), Corporate Governance, Jurisdictional Comparisons, 2013., str. 212. 
skupštine, te mora sadržavati upute kako glasovati o pojedinim točkama dnevnoga reda. Opunomoćenik može glasovati za račun dioničara i o onim točkama dnevnoga reda za koje je dobio uputu za glasovanje, a za koje nije prikupljao punomoći za glasovanje (čl. 142. st. 2. TUF-a). Međutim, valja istaknuti da talijansko pravo ne sadrži posebne odredbe o sankcijama ako punomoćnik glasuje protivno dobivenim uputama. $^{73}$

Prospekt i obrazac punomoći moraju dioničaru pružati dovoljno informacija za donošenje odluke kako glasovati o točkama dnevnoga reda za koje se prikupljaju punomoći. Odgovornost za potpunost informacija je na osobi koja prikuplja punomoći (promotoru) te je na njemu teret dokaza, u slučaju povrede te obveze.

\subsection{Primjeri iz prakse}

\subsubsection{Slučaj Cape Live - Italija}

Jedan od primjera organiziranoga prikupljanja punomoći za glasovanje na glavnoj skupštini u Italiji je slučaj Cape Live, u kojem se postupak organiziranog prikupljanja punomoći, provodio radi utjecanja na sastav upravnog odbora društva.

Manjinski dioničar Michele Bargauan, koji je držao nešto više od $2 \%$ dionica društva, započeo je postupak organiziranog prikupljanja punomoći za glasovanje na glavnoj skupštini društva Cape Live, koja je bila sazvana za 10. i 11. veljače 2011. godine. ${ }^{74}$ Zajedno s dioničarima čiju je podršku uživao, držao je oko 9,67 \% glasačkih prava u društvu.

Ta je inicijativa izazvala brzu reakciju kontrolne grupe dioničara koja je držala udio od 28,2 \% u temeljnom kapitalu društva Cape Live, predvođenu društvom Fenicia i Finross ${ }^{75}$ te private equity fondom Atlantis Capital Special Situations i grupom dioničara, a koji su 27. prosinca 2010. godine sklopili međudioničarski sporazum.

Postupak prikupljanja punomoći za glasovanje je bio iznimno uspješan, budući da je manjinski dioničar na glavnoj skupštini držao $75 \%$ glasačkih prava, čime je mogao utjecati na sastav upravnog odbora društva.

Nakon postupka prikupljanja punomoći za glasovanje na glavnoj skupštini društva Cape Live, u Italiji su provođeni i drugi postupci prikupljanja punomoći za glasovanje, ne samo radi utjecanja na sastav upravnog odbora društva. Ujedno je uočeno da postupke prikupljanja punomoći ne provode isključivo dioničari društva, već i osobe koji su imatelji obveznopravnih zahtjeva prema društvu. ${ }^{76}$

73 Sacchi, Roberto, Voto in base alla data di registrazione e voto per delega dopo l'attuazione della Direttiva azionisti, Giurisprudenza commerciale, vol. 39., br. 1., 2012., str. 31-65., ističe da bi takav glas bio ništetan te da bi to trebao biti razlog za nevaljanost odluka glavne skupštine donesenih na temelju tako danih glasova.

74 Poziv dioničarima dostupan je na stranici: http://www.alba-pe.com/sites/default/files/Avviso agli_Azionisti_di_Cape_Live.pdf (posjećeno 18.12.2016.).

75 Društvo Finross kontrolirao je Edoardo Rossetti, bivši predsjednik upravnog odbora društva Cape Live.

76 Tako je primjerice proveden postupak za stjecanje punomoći za glasovanje na glavnoj skupštini dioničkog društva Sopaf s ciljem utjecanja na uređenje položaja imatelja obveznica u društvu. Vidi više kod Ricciardiello, Edgardo, op. cit., str. 167. 


\subsubsection{Slučaj Eurotunnel-Francuska}

Jedan od najpoznatijih slučajeva gdje je uspješno korišten postupak organiziranog prikupljanja punomoći za glasovanje na glavnoj skupštini u Francuskoj je slučaj Eurotunnel, u kojemu je grupa manjinskih dioničara prikupila dovoljan broj punomoći, radi opoziva članova upravnog odbora.

Postupak prikupljanja punomoći za glasovanje na glavnoj skupštini društva Eurotunnel pokrenut je 2004. godine, dakle u vrijeme kada je francusko pravo dopuštalo dioničarima davanje punomoći za glasovanje drugim dioničarima, ali ne i trećim osobama koje nisu dioničari društva, što je izmijenjeno 2010. godine. ${ }^{77}$ Postupak prikupljanja punomoći za glasovanje vodio je manjinski dioničar Nicolas Miguet, koji je uživao podršku nekoliko međunarodnih institucionalnih ulagatelja. Na glavnoj skupštini koja je održana 7. travnja 2004. godine lista članova upravnog odbora koju je predložio Nicolas Miguet dobila je 63,42 \% glasova, odnosno glasove 64000 dioničara, što je činilo $35 \%$ udjela u temeljnom kapitalu društva. Valja istaknuti da je prosjek sudjelovanja dioničara na ranijim skupštinama društva Eurotunnel bio oko $10 \%$.

Praksa pokazuje da unatoč zakonodavnim izmjenama u Francuskoj nije povećan broj postupaka organiziranog prikupljanja punomoći, budući da postoje druge prepreke koje otežavaju ovaj postupak, npr. punomoćnik ne može s lakoćom utvrditi tko su manjinski dioničari društva, budući da se podatci o dioničarima moraju objaviti 16 dana prije održavanja glavne skupštine, što je kratak rok za dioničara koji namjerava pokrenuti postupak prikupljanja punomoći. Ujedno valja naglasiti da se dioničari koji prikupljaju punomoći izlažu riziku da ih se sukladno francuskim propisima smatra osobama koje djeluju zajednički, ako se punomoći stječu radi stjecanja kontrole nad društvom. ${ }^{78}$

\section{ZAKLJUČAK}

Države članice EU-a različito su pristupile uređenju organiziranog prikupljanja punomoći za glasovanje na glavnoj skupštini. S jedne strane je skupina država članica koje nisu izričito zakonskim odredbama uredile ovaj institut, dok je s druge skupina država članica koje izričito uređuju ovaj institut. Međutim, i unutar te skupine postoje značajne razlike. Hrvatsko pravo spada u prvu skupinu zemalja, dakle onih koje nemaju posebne odredbe o organiziranom prikupljanju punomoći za glasovanje na glavnoj skupštini. Stoga će se na takav način prikupljanja punomoći primjenjivati odredbe kojima se uređuje glasovanje putem opunomoćenika kao i posebne odredbe kojima se uređuje glasovanje putem kreditnih institucija i osoba koje djeluju na

77 Vidi infra t. 2.2.2.

78 Omaggio, Alexandre, Transposition de la Directive relative aux droits des actionnaires de sociétés cotées, La Semaine Juridique Entreprise et Affaires, br. 4., 2011., str. 1049., McDermott, Will, Buhart, Emery Jacques, Lafont, Nicolas, France, dostupno na: https://www.mwe.com/ /media/ files/thought-leadership/publications/2015/05/corporate-governance-2nd-edition--frenchchapter_/files/corporate-governancefrance/fileattachment/corporate-governancefrance.pdf (posjećeno 22.12.2016.). 
odgovarajući način.

Uočavajući položaj i mogućnost osobe koja je stekla veliki broj punomoći za glasovanje na glavnoj skupštini, utjecati na donošenje ključnih odluka u društvu, hrvatski bi zakonodavac trebao razmotriti uređenje organiziranog prikupljanja punomoći za glasovanje na glavnoj skupštini. To će primjerice doći do izražaja kada je riječ o glavnoj skupštini koja se održava za vrijeme trajanja postupka preuzimanja i na kojoj se odlučuje o primjeni protupreuzimateljskih mjera. ${ }^{79}$

Kod uređenja takva načina prikupljanja punomoći, nužno je odgovoriti na nekoliko pitanja. To je prije svega pitanje broja dioničara koji bi bio propisan kao prag čijim prelaskom nastaje obveza primjene posebnog postupka prikupljanja punomoći, a koji je u slovenskom zakonodavstvu određen na 50 dioničara koji drže dionice s pravom glasa, dok je u talijanskom zakonodavstvu potrebno da je zahtjev upućen prema više od 200 dioničara. Francusko zakonodavstvo ne propisuje broj dioničara kojima bi bio upućen ovaj zahtjev. Za davanje odgovora na to pitanje ključna je struktura dioničara u društvu. U hrvatskim društvima prevladava koncentrirana struktura dioničara. Dakle, za stjecanje glasačke kontrole u društvu, dovoljno je da je zahtjev upućen manjem broju dioničara, za razliku od onih pravnih poredaka u kojima prevladava disperzirana struktura dioničara. ${ }^{80}$

Daljnje je pitanje oblika u kojem bi se morala dati punomoć. Za zauzimanje stajališta o obliku u kojem se mora dati punomoć, treba voditi računa o odredbama Direktive o pravima dioničara, koja u čl. 11. propisuje da imenovanje opunomoćenika i obavijest društvu o imenovanju opunomoćenika moraju biti u pisanom obliku.

Nužno je naglasiti da će se dodatna zaštita dioničarima od kojih se traži davanje punomoći postići propisivanjem podataka koje je osoba koja pokreće postupak prikupljanja punomoći dužna objaviti. Slovenski, francuski i talijanski zakonodavac propisuju minimalne podatke koji se moraju objaviti te izričito propisuju minimalni sadržaj punomoći za glasovanje na glavnoj skupštini. Svi ispitivani pravni poredci koji izričito uređuju ovaj institut, nameću obvezu osobi koja provodi postupak organiziranog prikupljanja punomoći, objaviti svoje prijedloge za glasovanje o pojedinim točkama dnevnoga reda. Ujedno slovenski i talijanski zakonodavac, pružaju i daljnju zaštitu dioničarima, propisivanjem obveze traženja uputa za glasovanje. Valja naglasiti da Direktiva o pravima dioničara ne nameće nikakve obveze društvima u pogledu provjere ostvaruju li opunomoćenici pravo glasa u skladu s uputama dioničara, a isto tako ne propisuje niti sankcije ako opunomoćenik ne glasuje u skladu s dobivenim uputama. Dakle, države članice su slobodne urediti ova pitanja nacionalnim zakonodavstvom. Nužno je istaknuti da je opunomoćenik dužan poštovati volju dioničara, budući da on na glavnoj skupštini glasuje u ime dioničara koji mu je dao punomoć. Stoga ako je dobio uputu kako glasovati za pojedinu točku dnevnoga reda, dužan je pridržavati se dobivene upute. Upravo je taj aspekt još više naglašen ukoliko određeni dioničar

79 Zakon o preuzimanju dioničkih društava, Narodne novine, br. 109/07, 36/09, 108/12, 90/13, 99/13, 148/13, u čl. 42. st. 4. uređuje održavanje glavne skupštine na kojoj se odlučuje o primjeni protupreuzimateljskih mjera, gdje je izričito propisano da "Društvo treba olakšati dioničarima izdavanje punomoći za glasovanje, ukoliko je to moguće prema zakonu i statutu."

80 Zubović, Antonija, Stjecanje glasačke kontrole nad uvrštenim društvom (doktorska disertacija), Pravni fakultet Sveučilišta u Zagrebu, 2012., str. 14., 401. 
pokreće postupak organiziranog prikupljanja punomoći za glasovanje na glavnoj skupštini, radi utjecanja na donošenje odluke određenoga sadržaja.

Ovdje se otvara daljnje pitanje koje je bitno kod glasovanja opunomoćenika na glavnoj skupštini, a to je pitanje postojanja sukoba interesa. Naime, Direktiva propisuje da opunomoćenik može biti svaka fizička i pravna osoba koja ima poslovnu sposobnost. Dakle, dopušteno je da se kao opunomoćenik pojavi osoba koja se nalazi u određenom sukobu interesa s dioničarom koji joj je dao punomoć. Tako je primjerice Direktivom dana mogućnost državama članicama ograničiti ili isključiti ostvarivanje prava glasa dioničara putem opunomoćenika ako opunomoćenik nije dobio posebne upute za glasovanje za pojedinu odluku za koju opunomoćenik treba glasovati u ime dioničara. Dakle, ako bi država članica usvojila odredbu da, primjerice, članovi uprave i/ili nadzornog odbora ne mogu biti opunomoćenici, to bi bio strožiji zahtjev od onoga određen Direktivom. Istraživanje je pokazalo da su zakonodavci ispitivanih pravnih poredaka ipak ovom pitanju pristupili puno blaže. Tako primjerice i slovenski i francuski zakonodavac propisuju da je opunomoćenik dužan samo upozoriti dioničara o postojanju sukoba interesa. Talijanski je zakonodavac ovo pitanje uredio strožije, razlikujući položaj opunomoćenika u uvrštenim društvima od njegovog položaja u društvima koja nisu uvrstila svoje dionice na organizirano tržište kapitala. Tako se kod društava koja nisu uvrstila svoje dionice na organizirano tržište kapitala, punomoć ne može dati članovima organa društva, zaposlenicima društva, društvu koje nad njime ostvaruje kontrolu kao niti članovima organa i zaposlenicima toga društva. S druge strane, kod uvrštenih društava punomoć se može dati tim osobama, ali uz poštovanje odredaba o postojanju sukoba interesa, što znači da će oni moći glasovati u svojstvu opunomoćenika, pod uvjetom da su obavijestili dioničara o postojanju sukoba interesa te dobili uputu za glasovanje na glavnoj skupštini. Valja istaknuti da ako je opunomoćeniku isključeno pravo glasa na glavnoj skupštini, on ne bi mogao glasovati niti u svojstvu opunomoćenika. Takvo je stajalište izričito zauzeto u svim ispitivanim pravnim poredcima.

Vezano uz trajanje punomoći Direktiva daje mogućnost državama članicama ograničiti imenovanje opunomoćenika na jednu glavnu skupštinu ili na glavne skupštine koje se održavaju u određenom vremenskom periodu. U svim ispitivanim pravnim poredcima koji izričito uređuju organizirano prikupljanje punomoći za glasovanje na glavnoj skupštini, valjanost punomoći stečenih provođenjem postupka organiziranog prikupljanja punomoći ograničena je na jednu glavnu skupštinu.

Daljnje je pitanje sankcija zbog nepostupanja u skladu s propisanim obvezama. Posebno rješenje usvojio je francuski zakonodavac davanjem ovlasti trgovačkom sudu na području kojeg se nalazi sjedište društva, na zahtjev opunomoćitelja i za razdoblje od najdulje tri godine, oduzeti pravo na zastupanje na skupštinama tog trgovačkog društva. Sud ujedno može donijeti odluku o javnoj objavi izrečenih mjera. Takvu odluku sud može donijeti i na zahtjev samoga društva. Prema odredbama slovenskoga zakonodavstva ukoliko bi punomoći bile prikupljene protivno propisanim odredbama, one bi bile ništetne.

Kod prikupljanja punomoći za glasovanje na glavnoj skupštini pojavljuju se i druga otvorena pitanja. To je prije svega pitanje uvida u podatke o dioničarima 
društva kao i o postotku dionica koje drže. Valja istaknuti i povezanost ovog postupka s drugim institutima tržišta kapitala. Potrebno je sagledati ovu problematiku s aspekta nastanka obveze objavljivanja podataka o promjenama u postotku glasačkih prava u društvu. Ujedno je relevantno zauzeti stajalište o tomu izlažu li se osobe koje pokreću postupak organiziranog prikupljanja punomoći za glasovanje na glavnoj skupštini, mogućnosti postojanja zajedničkog djelovanja, u kom slučaju se otvara pitanje obveze objavljivanja ponude za preuzimanje.

\section{LITERATURA}

1. Abriani, N. et. al., Diritto delle società, Quinta edizione, Giuffrè Editore, 2012.

2. Aktiengesetz vom 6. September 1965 (BGBl. I S. 1089), posljednji put izmjenjen čl. 5. Zakona od 10. 5. 2016. (BGBl. I S. 1142).

3. Barbić, Jakša, Markovinović, Hrvoje, Parać, Zoran, Petrović, Siniša, Novela Zakona o trgovačkim društvima iz 2009., Novi informator, Zagreb, 2010.

4. Barbić, Jakša, Pravo društava, Knjiga druga, Društva kapitala, Organizator, Zagreb, 2010.

5. Barbić, Jakša, Pravo društava, Knjiga druga, Društva kapitala, Svezak I., Dioničko društvo, Organizator, Zagreb, 2013.

6. Barbić, Jakša, Sazivanje glavne skupštine i ostvarivanje prava dioničara nakon novele Zakona o trgovačkim društvima iz 2009., Zbornik 48. susreta pravnika, Opatija, 2010.

7. Baums, Theodor, Schmitz, Rainer, Shareholder Voting in Germany, Arbeitspapier Nr. 76, dostupno na: http://www.jura.uni-frankfurt.de/ifawz1/baums/Bilder_und_Daten/ Arbeitspapiere/paper76.pdf (posjećeno 03.12.2016.).

8. Behnke, Thorsten, Die Stimmrechtsvertretung in Deutschland, Frankreich und England, Neue Zeitschrift für Gesellschaftsrecht, 2000.

9. Bratina, Borut, Uresničevanje glasovalne pravice in pooblaščenci delničarjev, Sedemnajsto posvetovanje o aktualni problematiki s področja gospodarskega prava, Gospodarski subjekti na trgu - novosti in aktualna vprašanja gospodarskega prava, Portorož, 2009.

10. Bruno, Sabrina, Legal rules, Shareholders and Corporate Governance. The European Shareholder Rights' Directive and its impact on Corporate Governance of Italian Listed Companies: The Telecom s.p.a. case, Corporate Ownership \& Control, vol. 12., br. 2., 2015.

11. Bruno, Sabrina, Ruggiero, Eugenio, Public Companies and the Role of Shareholders: National Models Towards Global Integration, Kluwer Law International, 2011.

12. Buhart, Jacques, Lafont, Nicolas, u: Kawamura, Akira, Mori, Anderson, Tomotsune (edt.), Corporate Governance, Jurisdictional Comparisons, 2013.

13. Communication from the Commision to the European Parliament, the Council, the European Economic and Social Committee and the Committee of the Regions Action Plan: European company law and corporate governance - a modern legal framework for more engaged shareholders and sustainable companies, dostupno na: http://eur-lex. europa.eu/legal-content/EN/TXT/?qid=1453891145338\&uri=CELEX:52012DC0740 (posjećeno 16.11.2016.).

14. Cziraki, Peter, Renneboog, Luc, Szilagyi, Peter, G., Shareholder Activism through Proxy Proposals: The European Perspective, dostupno na: http://ssrn.com/abstract=1413125 (posjećeno 20.12.2016.).

15. Čulinović-Herc, Edita, Hasić, Tea, Sudjelovanje dioničara u radu glavne skupštine dioničkog društva prema noveli Zakona o trgovačkim društvima, Zbornik Pravnog fakulteta u Rijeci, vol. 32., br. 1., 2011. 
16. De Pra, Alberto, Deliberazione negativa votata in conflitto d'interessi e divieto di voto del socio-amministratore, Giurisprudenza Commerciale, br. 5., 2010.

17. Decreto Legislativo 24 febbraio 1998, n. 58, "Testo unico delle disposizioni in materia di intermediazione finanziaria, ai sensi degli articoli 8 e 21 della legge 6 febbraio 1996, n. 52", Gazzetta Ufficiale n. 71 del 26 marzo 1998 - Supplemento Ordinario n. 52.

18. Decreto Legislativo 27 gennaio 2010, n. 27 "Attuazione della direttiva 2007/36/CE, relativa all'esercizio di alcuni diritti degli azionisti di societa' quotate", Gazzetta Ufficiale del 5 marzo 2010, n. 53 - Supplemento Ordinario n. 43.

19. Di Amato, Sergio, Muscolo, Gabriella, Sciumbata, Gabriele, Le assemble nelle S.p.A., Giuffrè Editore, 2011.

20. Directive 2004/109/EC of the European Parliament and of the Council of 15 December 2005 on the harmonisation of transparency requirements in relation to information about issuers whose securities are admitted to trading on a regulated market and amending Directive 2001/34/EC, OJ L 390, 31.12.2004., str. 38-57.

21. Directive 2004/25/EC of the European Parliament and of the Council of 21 April 2004 on takeover bids, OJ L 142, 30. 4. 2004., str. 12-23.

22. Directive 2007/36/EC of the European Parliament and of the Council of 11 July 2007 on the exercise of certain rights of shareholders in listed companies, OJ L 184, 14.7. 2007., str. 17-24.

23. Eckbo, B. Espen, Paone, Giulia, Reforming Share-Voting Systems: The Case of Italy, Tuck School of Business Working Paper No. 2011-93, 2011.

24. Ferrucci, Annamaria, Ferrentino, Carmine, Società di capitali, società cooperative e mutue assicuratrici, Seconda edizione, Tomo I, Giuffrè Editore, 2012.

25. Gérard Notté, Exercice de certains droits des actionnaires de sociétés cotées (Ord. $n^{\circ}$ 2010-1511, 9 déc. 2010), La Semaine Juridique Entreprise et Affaires, br. 50., 2010.

26. Gesetz zur Namensaktie und zur Erleichterung der Stimmrechtsausübung (Namensaktiengesetz - NaStraG) vom 18. Januar 2001., BGB1. I S. 123.

27. Hanloser, Stefan, Proxy-Voting, Remote-Voting und Online-HV: § 134 III 3 AktG nach dem NaStraG, Neue Zeitschrift für Gesellschaft, br. 8., 2001.

28. Heckel, Gilles, Larcena, Antoine, Panorama des aménagements apportés aux droits des actionnaires de sociétés cotées suite à la transposition de la directive 2007/36/CE du 11 juillet 2007, Revue de Droit bancaire et financier, br. 5., 2011.

29. Henssler, Martin, Strohn, Lutz, Liebscher, Thomas, Aktiengesetz Kommentar, Gesellschaftrecht, Verlag C.H. Beck München, 2. Aufl., 2014.

30. Hölters, Wolfgang, Hirschmann, Jörn, Aktiengesetz Kommentar, C. H. Beck, 2. Auflage, 2014.

31. Hüffer, Üve, Aktiengesetz Kommentar, 9. Aufl., 2010.

32. Hüffer, Uwe, Aktiengesetz, C. H. Beck, 11. Aufl., 2014.

33. Jurić, Dionis, Pravno uređenje unutarnjeg korporacijskog upravljanja (corporate governance) u dioničkim društvima u hrvatskom i usporednom pravu društava (doktorska disertacija), Sveučilište u Rijeci, Pravni fakultet, Pravni fakultet, Rijeka, 2005.

34. Kreditwesengesetz in der Fassung der Bekanntmachung vom 9. September 1998, BGB1. I S. 2776, posljednji put izmijenjen čl. 3. Zakona od 30. 06. 2016., BGBl. I S. 1514.

35. La nuova disciplina del funzionamento dell'assemblea delle società quotate, Circolare Assonime n. 14/2011, Rivista delle Società, br. 2-3, 2011.

36. Le Nabasque, Hervé, Droits des actionnaires des sociétés cotées, Revue de Droit bancaire et financier, br. 1., 2011.

37. Lenz, Susanne, Die Gesellschaftsbenannte Stimmrechtsvertretung (Proxy-Voting) in der Hauptversammlung der deutschen Publikums-AG, Duncker \& Humblot, Berlin, 2005.

38. Lieberam-Schmidt, Sabine, Die Stimmrechtsvertretung im Aktien- und GmbH-Recht, Dissertation, 2010.

39. Markovinović, Hrvoje, Tepeš, Nina, Ostvarivanje prava glasa po dionicama u skrbništvu, 
Zbornik radova "Financiranje, upravljanje i restrukturiranje trgovačkih društava u doba recesije“, Pravni fakultet u Rijeci, 2011.

40. Markovinović, Hrvoje, Tepeš, Nina, Skrbništvo nad vrijednosnim papirima, Zbornik 49. susreta pravnika, Opatija, 2011.

41. Masouros, E., Pavlos, Is the EU Taking Shareholder Rights Seriously?: An Essay on the Impotence of Shareholdership in Corporate Europe, European Company Law, vol. 7., br. 5., 2010.

42. Mayson, Stephen, French, Derek, Ryan, Christopher, Company Law, Oxford University Press, 2013., str. 389., Hannigan, Brenda, Company law, Third edition, Oxford University Press, 2012.

43. McDermott, Will, Buhart, Emery Jacques, Lafont, Nicolas, France, dostupno na: https://www.mwe.com/ /media/files/thought-leadership/publications/2015/05/ corporate-governance-2nd-edition--french-chapter_/files/corporate-governancefrance/ fileattachment/corporate-governancefrance.pdf (posjećeno 22.12.2016.).

44. New Tools to Encourage Shareholder Participation in the Life of Italian Listed Companies, dostupno na: http://www.shearman.com/ /media/Files/NewsInsights/ Publications/2010/04/New-Tools-to-Encourage-Shareholder-Participation _ / Files/View-full-memo-New-Tools-to-Encourage-Shareholde_/FileAttachment/ EC042110NewToolstoEncourageShareholderParticipat_.pdf(posjećeno 15. 12. 2016.).

45. Noack, Ulrich, Die Aktionärsrechte-Richtlinie, dostupno na: http://papers.ssrn.com/ sol3/papers.cfm?abstract_id=1138735 (posjećeno 03.12.2016.).

46. Noack, Ulrich, Die Aktionärsrechte-Richtlinie, u: Festschrift für Harm Peter Westermann zum 70. Geburtstag, Verlag Dr. Otto Schmidt, Köln, 2008.

47. Noack, Ulrich, Die organisierte Stimmrechtvertretung auf Hauptversammlungen insbesondere durch die Gesellschaft, u: Festschrift für Marcus Lutter zum 70. Geburtstag, Verlag Dr. Otto Schmidt, Köln, 2000.

48. Noack, Ulrich, Hauptversammlung und Internet: Information - Kommunikation Entscheidung, dostupno na: http://ssrn.com/abstract=646723 (posjećeno 22.12.2016.).

49. Ochmann, Florian, Die Actionärsrechte-Richtlinie, Auswirkungen auf das deutsche und europäische Recht, De Gruyter Recht, Berlin, 2009.

50. Omaggio, Alexandre, Transposition de la Directive relative aux droits des actionnaires de sociétés cotées, La Semaine Juridique Entreprise et Affaires, br. 4., 2011.

51. Parać, Zoran, Dileme oko preuzimanja javnih dioničkih društava, Pravo u gospodarstvu, god. 42., svezak 4., 2003.

52. Petrović, Siniša, Pripajanje dioničkih društava i druge koncentracije u pravu društava (doktorska disertacija), Pravni fakultet u Zagrebu, 1998.

53. Presuda Visokog trgovačkog suda RH od 04. lipnja 2002. godine u predmetu br. Pž$1740 / 02$.

54. Proposal for a Directive of the European Parliament and of the Council amending Directive 2007/36/EC as regards the encouragement of long-term shareholder engagement and Directive 2013/34/EU as regards certain elements of the corporate governance statement, dostupno na: http://eur-lex.europa.eu/legal-content/EN/ TXT/?qid=1398680488759\&uri=COM:2014:213:FIN (posjećeno 16.11.2016.)

55. Ratschow, Eckart, Die Aktionärsrechte-Richtlinie - neue Regeln für börsennotierte Gesellschaften, Deutsches Steuerrecht, br. 32., 2007.

56. Ricciardiello, Edgardo, La nouova disciplina in material di sollecitazione delle deleghe di voto: inizia la stagione italiana dei proxy fights?, Giurisprudenza Commerciale, br. 1., 2012.

57. Sacchi, Roberto, Voto in base alla data di registrazione e voto per delega dopo l'attuazione della Direttiva azionisti, Giurisprudenza commerciale, vol. 39., br. 1., 2012.

58. Schneider, Anzinger, Institutionelle Stimmrechtsberatung und Stimmrechtsvertretung "A quiet guru's enormous clout", Neue Zeitschrift für Gesellschaft, br. 88., 2007. 
59. Schockenhoff, Martin, Proxy Fights - bald auch in Deutschland?, Einwerben von Stimmrechtsvollmachten durch Aktionäre und Verwaltung, Neue Zeitschrift für Gesellschaft, br. 17., 2015.

60. Summary of the informal discussion concerning the initiative on shareholders engagement, Brussels, 17 April 2013, str. 5., dostupno na: http://ec.europa.eu/ internal_market/company/docs/shareholders/120417_summary-initiative-shareholdersengagement_en.pdf (posjećeno 10.11.2016.)

61. Visco, Claudio, Pucci, Ernesto u: Kawamura, Akira, Mori, Anderson, Tomotsune (edt.), Corporate Governance, Jurisdictional Comparisons, First Edition, 2013.

62. Zakon o gospodarskih družbah, Uradni list RS, br. 33/11, 91/11, 32/12, 57/12, 44/13, $82 / 13,55 / 15$.

63. Zakon o kreditnim institucijama, Narodne novine, br. 159/13, 19/15.

64. Zakon o obveznim odnosima, Narodne novine, br. 35/05, 41/08, 125/11, 78/15.

65. Zakon o preuzimanju dioničkih društava, Narodne novine, br. 109/07, 36/09, 108/12, 90/13, 99/13, 148/13.

66. Zakon o prevzemih, Uradni list, br. 79/06, 67/07, 01/08, 68/08, 35/11, 105/11, 10/12, $38 / 12$

67. Zakon o trgovačkim društvima, Narodne novine br. 111/93, 34/99, 121/99, 52/00, 118/03, 107/07, 146/08, 137/09, 125/11, 152/11, 111/12, 68/13, 110/15.

68. Zakon o tržištu kapitala, Narodne novine br. 88/08, 146/08, 74/09, 54/13, 159/13, 18/15, $110 / 15$.

69. Zetzsche, Dirk, Shareholder Interaction Preceding Shareholder Meetings of Public Corporations - A Six Country Comparison, European Corporate \& Finance Law Review - ECFR 2:1, 105, 2005., dostupno na: http://ssrn.com/abstract=648982 (posjećeno 04.12.2016.)

70. Zetzsche, Dirk, Shareholder Passivity, Cross-Border Voting and the Shareholder Rights Directive, dostupno na: http://ssrn.com/abstract=1120915 (posjećeno 20.12.2016.).

71. Zetzsche, Dirk, Virtual Shareholder Meetings and the European Shareholder Rights Directive - Challenges and Opportunities, dostupno na: http://ssrn.com/abstract=998429 (posjećeno 20.12.2016.).

72. Zubović, Antonija, Stjecanje glasačke kontrole nad uvrštenim društvom (doktorska disertacija), Pravni fakultet Sveučilišta u Zagrebu, 2012. 
Summary

\section{PROXY SOLICITATION AS A METHOD OF OBTAINING VOTING CONTROL AT THE GENERAL MEETING - OPEN QUESTIONS}

In the article the author analyzes the proxy solicitation as a method for acquiring voting control in a company pointing out to the open issues in its application. Since the Shareholders' Rights Directive does not explicitly regulate the proxy solicitation, it is left to the discretion of each EU Member State legislator. There are two groups of Member States in regards to this matter - Member States that do not regulate the proxy solicitation process and those that have adopted specific provisions regulating proxy solicitation. However, it should be noted that, even within the second group of Member States, approaches to regulating specific issues in the proxy solicitation adopted by the national legislators vary. Furthermore, Member States without specific provisions are now questioning the actual necessity for their implementation. In the conclusion, the author proposes solutions to be adopted in Croatian law in this respect.

Keywords: proxy solicitation, proxy contest, proxy voting, proxy, shareholders' meeting, voting rights, Shareholders'Rights Directive.

Zusammenfassung

\section{ORGANISIERTE STIMMRECHTSVERTRETUNG ALS EIN WEG ZUR ERHÖHUNG DER STIMMRECHTSKONTROLLE AN DER HAUPTVERSAMMLUNG - OFFENE FRAGEN}

Das Thema dieser Arbeit ist die organisierte Sammlung von Vertretungen für die Ausübung von Stimmrechten in der Hauptversammlung. Offene Fragen der Anwendung dieser Regelung werden dabei besonders unter die Lupe genommen. Da dieses Rechtsinstitut nicht durch die Richtlinie über die Ausübung bestimmter Rechte von Aktionären in börsennotierten Gesellschaften geregelt ist, haben die Mitgliedstaaten verschiedene Wege in seiner Regulierung eingeschlagen. Während einige Mitgliedstaaten die Sammlung von Stimmrechtsvertretung an der Hauptversammlung nicht ausdrücklich regeln, haben andere Sonderverordnungen dazu verabschiedet. Bei den letzteren Mitgliedstaaten sind allerdings unterschiedliche Regulierungsansätze in Bezug auf spezifische Aspekten $\mathrm{zu}$ beobachten. Es ist zu betonen, dass die Notwendigkeit einer Regulierung der Sammlung von Stimmrechtsvertretungen an der Hauptversammlung immer mehr in den Vordrgrund tritt. Schlussfolgernd werden dazu entsprechende Lösungen für das kroatische Recht vorgelegt. 
Schlüsselwörter: organisierte Sammlung von Stimmrechtsvertretungen bei der Hauptversammlung, Vertretungen, Bevollmächtigung, Hauptversammlung, Stimmrecht, Die Aktionärsrechte Richtlinie.

\author{
Riassunto
}

\title{
LA SOLLECITAZIONE DELLE DELEGHE DI VOTO NELL'ASSEMBLEA GENERALE QUALE MODALITÀ DI INFLUENZA SULLA ATTIVITÀ DECISIONALE NELLA SOCIETÀ - QUESTIONI APERTE
}

Nel lavoro si tratta della sollecitazione delle deleghe di voto nell'assemblea generale, rilevando le questioni aperte concernenti l'utilizzo di tale pratica. Posto che la Direttiva sui diritti degli azionisti nelle società quotate non regola espressamente tale istituto, gli Stati membri dell'UE hanno preso posizioni diverse con riguardo alla sua disciplina. Da un lato, vi sono Stati membri che non hanno regolato esplicitamente la sollecitazione delle deleghe di voto nell'assemblea generale; mentre, dall'altra parte, vi sono Stati membri che mediante disposizioni particolari regolano tale istituto. Tuttavia, anche all'interno di codesto gruppo di Stati membri si notano diversi approcci nella regolamentazione di singole questioni. Va evidenziato che negli Stati membri dell'UE, dove la sollecitazione delle deleghe di voti nell'assemblea generale non trova disciplina espressa, sempre più spesso emerge l'esigenza di disciplinare giuridicamente tale aspetto. Pertanto, in chiusura, si danno dei suggerimenti per le soluzioni da adottarsi nel nostro diritto interno.

Parole chiave: sollecitazione delle deleghe di voto nell'assemblea generale, deleghe, delegato, assemblea generale, diritto di voto, Direttiva sui diritti degli azionisti. 